\title{
Objectives and Constraints of Entrepreneurs: Evidence from Small and Medium Size Enterprises in Russia and Bulgaria
}

By: Francesca Pissarides, Miroslav Singer, and Jan Svejnar

Working Paper Number 346

October 2000 


\title{
Objectives and Constraints of Entrepreneurs: Evidence from Small and Medium Size Enterprises in Russia and Bulgaria
}

\author{
Francesca Pissarides* \\ Miroslav Singer** \\ Jan Svejnar***
}

October 2000

\begin{abstract}
We analyze the principal objectives and constraints of small and medium enterprises (SMEs), using data from a survey of 437 owners and top managers (CEOs) of SMEs in Russia and Bulgaria. The CEOs display similar views and identify a small number of specific constraints as being the most important ones. The constraint on external financing is a particularly serious one and the SMEs use internal finance as a fall-back option. Our econometric analysis indicates that characteristics of the entrepreneur, firm and the firm's environment are important but varying determinants of which constraints are identified as the most important ones. Our results also suggest that the nature of disruption of production and of the financial constraints after the fall of central planning was more ubiquitous and all-encompassing in Russia than in Bulgaria.
\end{abstract}

Journal of Economic Literature Classification Numbers: D2, G3, L2, L5, P2.

* $\quad$ European Bank for Reconstruction and Development

** Expandia and CERGE-EI

*** The William Davidson Institute at the University of Michigan Business School, Department of Economics at the University of Michigan, and CERGE-EI

The research was in part supported by a grant from the European Bank for Reconstruction and Development. We would like to thank David Hajman and Martin Hlusek of CERGE-EI for valuable computational assistance. The paper benefited from presentations at EBRD, University of Michigan and CERGE-EI. We are solely responsible for any remaining errors. 


\section{Non-technical Summary}

In the present study, we contribute to the understanding of the principal objectives of small and medium size enterprises (SMEs) and of the various dimensions of constraints affecting their behavior. Our work has been motivated by the premise that in order to formulate a coherent strategy vis a vis entrepreneurs and the SME sector, it is necessary to (a) understand the objectives of these firms, (b) comprehend how different constraints affect SME formation and performance, and (c) be able to rank the relative severity of these constraints. In order to achieve this goal, we have designed a flexible survey instrument and administered it to owners and top managers of SMEs in Russia and Bulgaria. The survey allows us to (a) identify the principal objectives of SMEs, (b) rate and rank the severity of different types of constraints faced by the SMEs without needing to resort to subjective interpretations and (b) employ the instrument in a comparative setting across different economies. We carry out an econometric analysis of the information obtained from the questionnaire and draw conclusions about the behavior of SMEs in transition economies.

Our study of stratified random samples of 216 Russian and 221 Bulgarian SMEs shows a remarkable similarity of views of their owners/top managers (CEOs) with respect to objectives and constraints that they face. This finding suggests that the nature of issues confronting SMEs and the policies that may be formulated to assist them are similar across the transition economies. The CEO responses and data from their firms yield the following specific conclusions:

1. The SMEs in the two economies are primarily recently created and privately owned firms that are characterized by highly concentrated ownership. The two most important objectives of their CEOs are achieving the highest possible profit and output growth. While for new and small firms these two objectives may represent the same goal, the emphasis on output growth may also signal the presence of obstacles to growth. In the future, researchers ought to examine in depth these two competing explanations. Resolving this issue is important from both the academic and policy standpoint.

2. Most CEOs in both countries perceive to be hampered by a relatively small number of specific constraints. The five constraints that they cite most frequently as being most important in both countries are: (i) "suppliers are often not ready to deliver", (ii) the firm is facing "financing problems that hinder expanding production", (iii) the firm is facing high "level of interest rates", (iv) the firm is facing constraints on "getting land, office space and buildings", and (v) "other production constraints".

3. Constraints on obtaining external financing and the high cost of this financing are hence two of the top five constraints cited by most CEOs. The lack of credit finance was also cited by the CEOs as being the most important obstacle to increasing local sales, and it also appeared as the most important constraint with respect to increasing exports. Moreover, the constraint appears to be binding across the board, since the probability of it being selected as the most important constraint to expanding production is unrelated to manager-, firm- or sectorspecific variables. Finally, only about a third of the surveyed firms report receiving a loan from a financial institution over the pas three years and an even smaller fraction have heard about special financing programs for SMEs. Our principal finding is hence that the external financing constraint is a serious one. We also find that firms reinvest profits while operating 
under the external financing constraint. We hence conclude that financial constraints hamper SME growth and that the use of internal finance by SMEs represents a fall-back option. In this sense our study provides evidence that is contrary to the findings of Johnson, McMillan and Woodruff (1999). Our evidence is consistent, however, with the findings of Rajan and Zingales (1998), Winker (1999) and Lizal and Svejnar (2000).

4. Our econometric analysis of the determinants of the most important constraints indicate that all three sets of factors (characteristics of the entrepreneur, of the firm and of the firm's environment) are important. However, their effect is not always uniform across countries and constraints. For example, more educated entrepreneurs are better able to ensure that suppliers deliver and in Bulgaria they are also better able to get around the problem of high interest rates. Firm-specific factors are found to be important in that larger size firms for instance suffer more from unreliable supplier deliveries, capital intensive firms complain more about the problem of high interest rates and more established (older) and larger firms are better able to cope with problems of getting land, office space and buildings. Environmental factors, which we capture by the sectoral location of the firm, are important but their effect often differs in the two economies. In Bulgaria, firms in manufacturing suffer more than other firms from supplier delivery problems, while the situation is reverse in Russia. Yet, in Russia manufacturing firms suffer more than others from the problem of getting land, office space and buildings, while the situation is just the opposite in Bulgaria. Finally, we find that the most important constraints in the areas of production and finance are all-encompassing in Russia in that they affect SMEs irrespective of the characteristics of the CEO, the firm, or the sector of activity. In contrast, in Bulgaria the severity of the most important constraints in these two areas varies systematically with the CEO, firm and sectoral characteristics. These differences suggest that the nature of disruption of production and of the financial constraints after the fall of central planning was more ubiquitous and all-encompassing in Russia than in Bulgaria. Hence, our empirical evidence is consistent with the hypothesis that the disorganization phenomenon modelled for instance by Blanchard and Kremer (1997) and Roland and Verdier (1999) was more prevalent in the former Soviet Union than in the satellite countries of Central and Eastern Europe.

5. Finally, while SMEs would clearly benefit in their development if they had fair access to doing business with the state sector, our findings indicate that the state firms and other government institutions discriminate or project the image that they discriminate against SMEs in allocating contracts. Moreover, the state's delinquency in making payments for goods delivered and services rendered makes it difficult for the financially strapped SMEs to do business with the state sector. 


\section{Objectives and Constraints of Entrepreneurs: Evidence from Small and Medium Size Enterprises in Russia and Bulgaria}

\section{Introduction}

Entrepreneurs, start-up companies and small and medium size enterprises (SMEs) played a very limited part under central planning. Their relative absence reflected planners' difficulties in controlling a large number of small and independent agents, as well as their belief in the existence of economies of scale. ${ }^{\mathrm{A}}$ As the central controls were lifted, new entrepreneurs rapidly emerged and in a number of countries they became a principal driving force of economic development. In the Czech Republic, for example, manufacturing firms with fewer than 25 employees constituted $0.8 \%$ of all firms and accounted for $0.0 \%$ of total manufacturing output in 1989. By 1993, these firms constituted $89.9 \%$ of all manufacturing firms and produced $10.6 \%$ of manufacturing output (Zemplinerova and Stibal, 1995). Many of these small firms also grew rapidly in size. By 1994, many of them moved into the next size category of firms with 25-200 employees, accounting for the growth in its share of output from $0.1 \%$ in 1989 to $11.3 \%$ in 1993 and $14.2 \%$ in 1994. Similarly, (EBRD, 1993) estimated that over 1.5 million small businesses were in existence in Poland by the end of 1992 and Gomulka (1994) reported that the growth of output in Poland between 1992 and 1994 was accounted for primarily by the booming SME sector.

While SMEs thus constitute very dynamic firms, their behavior is not yet well understood and limited evidence suggests that they often face economic, institutional and legal obstacles,

\footnotetext{
${ }^{1}$ EBRD (1995) for instance reports that while SMEs accounted for over two-thirds of the labor force in Czechoslovakia and Hungary in the early 1930s, by 1989 this share fell to less than one-third. Moreover,
} 
including limited access to working capital and long term credit, legal and regulatory restrictions, inadequate infrastructure, and limited managerial and technical expertise. The issue has received some attention from theorists but empirical evidence has been sketchy.

In the present study, we contribute to the understanding of the principal objectives of SMEs and of the various dimensions of constraints affecting their behavior. Our work has been motivated by the premise that in order to formulate a coherent strategy vis a vis entrepreneurs and the SME sector, it is necessary to (a) understand the objectives of these firms, (b) comprehend how different constraints affect SME formation and performance, and (c) be able to rank the relative severity of these constraints. In order to achieve this goal, we have designed a flexible survey instrument and administered it to owners and top managers of SMEs in Russia and Bulgaria. The survey allows us to (a) identify the principal objectives of SMEs, (b) rate and rank the severity of different types of constraints faced by the SMEs without needing to resort to subjective interpretations and (b) employ the instrument in a comparative setting across different economies. We carry out an econometric analysis of the information obtained from the questionnaire and draw conclusions about the behavior of SMEs in transition economies.

\section{Methodology}

\subsection{Theoretical Underpinnings}

There have been several strands of the theoretical literature dealing with the factors that affect the emergence and performance of firms. Broadly speaking, the factors can be divided into those dealing with the entrepreneur, the structure of the firm, and the environment in which the

while the average size of an enterprise in these two economies grew to 2000 workers by 1989, the corresponding figure in the European Union was seven workers. 
entrepreneurs and firms operate. The issue of what personal or group characteristics make good entrepreneurs is an old one. Among individual characteristics, education has for instance been given emphasis in the human capital literature, while factors such as ethnicity and social background have featured in the anthropological and sociological studies. Group characteristics of entrepreneurs have been analyzed in the literatures dealing with owner-managed firms, separation of ownership and control, labor-managed or worker-owned firms, state-owned enterprises, and nonprofit organizations (see e.g., Williamson, 1985, Hart and Moore, 1990, and Bonin, Jones and Putterman, 1993). The structure or internal organization of firms has been studied primarily from the standpoints of bounded rationality, agency problems and strategic behavior (see e.g., Hurwizc, 1973, Milgrom and Roberts, 1990, and Ben-Ner, Montias and Neuberger, 1993). Finally, the environmental factors usually refer to the existence and functioning of the financial and other markets, the extent of development of infrastructure, and the presence of a legal framework, regulation and institutions of enforcement. In the transition context, considerable emphasis has also been placed on the achievement of macroeconomic stability (see e.g., Fischer, Sahay and Vegh, 1996).

In the context of the environment faced by entrepreneurs and firms, a question has arisen about the effects on firms of financial constraints brought about by the underdevelopment of financial markets in the transition and other developing economies. A large theoretical literature, reviewed by Levine (1997), points to the importance of financial sector development for economic growth through better identification of investment projects, better availability and lower cost of external financing to firms, improved risk taking, technological innovation, and 
other factors. In this context, Rajan and Zingales (1998) present industry-level evidence from a large sample of countries showing that firms needing external finance tend to develop slower in countries with less developed financial markets. Similarly, in their analysis of the population of Czech industrial firms with 25 or more workers, Lizal and Svejnar (2000) find that smaller firms (especially limited liability companies and cooperatives) have lower rates of investment and show signs of capital rationing in that their investment depends on the availability of internal funds. In contrast, Johnson, McMillan and Woodruff (1999) find in a survey of private manufacturing firms in Poland, Romania, Slovakia, Ukraine, and Russia that the absence of external financing does not prevent firms from investing. They conclude that the financial constraint is not restrictive in that internal finance can substitute for external finance.

In this paper, we examine the absolute and relative importance of a wide range of potential constraints facing small and medium size firms in Bulgaria and Russia. Our results indicate that several constraints are almost uniformly viewed as greatly restricting SME operations, with the lack or high cost of external financing being ranked on the top of the list. We also find that firms reinvest profits while operating under the external financing constraint. We hence conclude that financial constraints hamper SME growth and development and that the use of internal finance by SMEs represents a fall-back option.

\subsection{The Survey}

During the summer of 1995 we administered an extensive questionnaire to the owners and/or chief executive officers (hereafter CEOs) in a sample of 216 firms in the Krasnodar region of Russia (hereafter Russia) and 221 firms in Bulgaria. The goal of the interviews was to obtain 
information about the objectives of the firms and about the absolute and relative importance of the principal constraints faced by the firms. In order to assess the factors that lead managers to select particular constraints as being the most severe, we also collected information on the characteristics of the CEO, the firm, and the sector of the firm's operation.

In the main body of our questionnaire we focused on identifying the absolute and relative severity of the constraints faced by the SMEs in the areas of 1) production, 2) technology, 3) procurement of non-labor inputs, 4) sales, 5) finance, 6) infrastructure, 7) regulation and taxation, 8) labor, and 9) business services. Within each of these nine areas, each CEO was asked to rate on a scale from 1 (unimportant) to 5 (very important) the severity of several specific constraints. Each CEO was then provided with a complete list of the specific constraints that he had rated as very important (5) and, for questions in which he had rated no constraint as very important, he was also presented with constraints that he had rated as important (number 4 on the scale). The CEOs were then asked to examine this list of highly rated constraints from all the areas and to identify and rank the ten most important ones. In this way we have obtained (a) the absolute rating of the various specific constraints and information on the most important constraint (partial ranking) within each area, and (b) the relative ranking for the top ten highly rated specific constraints, irrespective of area.

In addition to tabulating the responses, we have used multinomial logit regressions to evaluate the extent to which CEO-specific, firm-specific and sectoral variables explain which constraints the CEOs identify as being the most important ones. 


\subsection{The Samples}

The samples constitute regionally stratified random samples based on the best data that we could obtain on the population of SMEs in Bulgaria and Russia. ${ }^{\square}$ As has been done in other enterprise-level surveys, the lack of historical data has forced us to sample existing firms and to collect current and retrospective information about them. This approach has the advantage of being feasible and affordable. Its drawback is that it produces duration bias. The bias stems from the fact that some firms did not perform well and closed down before the date of our sampling, while others were very successful and outgrew the category of small and medium sized firms. The usual sampling procedure thus excludes (truncates) the worst and best performing enterprises and oversamples firms that survive in a given category for relatively long periods of time. In order to minimize the duration bias, we set a relatively high upper limit on the number of workers (200 vs.the usual 100) in the selection of SMEs. ${ }^{2}$ The summary statistics related to the samples firms are reported in the Appendix. As may be seen from the Appendix, the SMEs in the two economies are primarily recently created and privately owned firms that are characterized by highly concentrated ownership.

After providing information about the objectives of their firms, the CEOs were asked a battery of questions about the obstacles and constraints they faced. As mentioned earlier, we formulated the questions in such a way as to obtain the best possible absolute and relative valuation of the severity of various constraints.

\footnotetext{
${ }^{2}$ In Russia the firms are located within the Krasnodar region, while in Bulgaria the firms are mostly located in the greater Sofia region.

${ }^{3}$ We have also made considerable effort to trace some of the extinct firms but this effort eventually proved unsuccessful.
} 


\section{Objectives of the Firms}

The CEOs were presented with a list of possible objectives and they were asked to rate

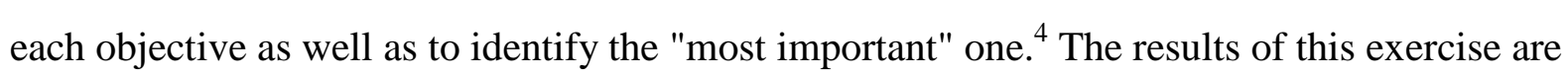
presented in Table 1. In each country there is virtually no difference between the objectives identified as important by the entire sample of firms and the sub-sample composed of private firms only. However, while both the Russian and Bulgarian SMEs tend to identify output and profit as "very important" as well as the "most important" objectives, in Russia the SMEs place somewhat more emphasis on profit, while in Bulgaria they place more emphasis on output. Indeed, while the same percentage (71\%) of Russian firms rate profit and output as "very important", $72 \%$ of Bulgarian firms rate output but only $44 \%$ rate profit as "very important". Moreover, while $49 \%$ of the Russian firms identify profit and $38 \%$ output as the "most important" objective, the respective percentages in the Bulgarian sample are 26\% and 52\%. Our retrospective questions indicate that the objectives appear to be stable over time and unrelated to company ownership.

Overall, the SMEs hence place emphasis on both profit and output maximization. For small firms, the two goals may of course be mutually consistent as growth may lead to increased profitability and improved likelihood of survival. ${ }^{\mathrm{G}}$ Nevertheless, in future research it will be desirable to examine more systematically the almost universally accepted assumption that the newly created firms in the transition economies behave as profit maximizers.

\footnotetext{
${ }^{4}$ The list consisted of the following objectives: achieve highest possible profit, output, employment, wages, and non-wage benefits, prepare for privatisation (if state owned), prevent of social conflict, and other.
} 


\section{Obstacles and Constraints Faced by the Entrepreneurs}

\subsection{The Analytical Approach}

In evaluating CEOs' responses about constraints, we use both cross tabulations and multinomial logit regressions. In the logits, we focus on explaining the determinants of the probability that the SME cites a given constraint as being the most important one. In accordance with the conceptual framework discussed in Section 2.1, the explanatory variables that we use reflect the characteristics of the entrepreneur, the firm, and the environment in which the firm operates:

Characteristics of the entrepreneur:

Education level of the CEO

\section{Characteristics of the Firm:}

Number of years since the firm acquired its current legal status (age of the firm) Percentage of the firm's capital owned by all private parties (ownership of the firm) Number of employees (firm size)

Capital-labor ratio (relative factor intensity) Sales per employee (labor productivity and ability to sell the products) Percentage of the firm's capital leased to others

\section{Environment of the Firm:}

Share of firm's output in manufacturing (sectoral location of the firm) Share of firm's output in trade (sectoral location of the firm).

The estimation of the parameters of the linear multinomial logit models is based on the specification

\footnotetext{
5 The overwhelming majority of enterprise closures takes place in enterprises with less than 10 employees not just in transition countries but also in EU countries (Eurostat).

${ }^{6}$ The corresponding OLS and probit regressions yield similar results.
} 
$\operatorname{Prob}\left[y_{i}=j\right]=\frac{\exp \left(\beta_{j}{ }^{\prime} x\right)}{\sum_{j} \exp \left(\beta_{j}{ }^{\prime} x\right)}, \quad j=0,1, \ldots, J$

where $\operatorname{Prob}\left[y_{i}=j\right]$ is the probability that the CEO cites a given constraint as being the most important one, $x$ is a vector of the explanatory variables defined above and $\beta_{j}$ is a vector of associated parameters. While the estimation of the multinomial logit model is based on a straightforward numerical optimisation (provided it is possible to identify the large number of parameters), the interpretation of the estimated coefficients is somewhat more complex. In contrast to the binomial models, the signs of the cofficients on individual variables do not necessarily correspond to the signs of their corresponding probability derivatives. In particular, letting $p_{j}$ stand for $\operatorname{Prob}[\mathrm{Y}=\mathrm{j}]$ for all $\mathrm{J}$, it is necessary to calculate the estimated asymptotic probability derivatives $\partial p_{j} / \partial x$ and their asymptotic variance-covariance matrices $\mathrm{V}\left(\partial p_{j} / \partial x\right)$.

Given the large number of coefficients that we need to estimate in our system of logit equations, we have carried out this calculation by expressing the estimates of $\partial p_{j} / \partial x$ as

$$
p_{j}\left(\beta_{j}-\bar{\beta}\right)
$$

where $\bar{\beta}=\sum_{j} p_{j} \beta_{j}$, and the estimate of $\mathrm{V}\left(\partial p_{j} / \partial x\right)$ as

$$
\text { Asy. } V\left(\partial p_{j} / \partial x\right)=\sum_{l} \sum_{m} V_{j l} A s y \cdot \operatorname{Cov} \cdot\left[\beta_{l}, \beta_{m}{ }^{\prime}\right] V_{j m}{ }^{\prime}, \mathrm{j}=1, \ldots, \mathrm{J}
$$

\footnotetext{
${ }^{7}$ For example, should the coefficient on age of firm in a linear model for the third constraint be positive, this does not mean that the probability of the third constraint being selected as most important increases with the firm's age.
} 
where $V_{j 1}=p_{j}\left[1(j=1)-p_{1}\right] I+\left[1(j=1)-2 p_{1}\right] \partial p_{j} / \partial x x^{\prime}$, with $1(j=1)=1$ if $j=1$ and 0

otherwise, and $I$ is a vector of $1 \mathrm{~s}$. The coefficients and standard errors reported in the tables of this paper are hence the asymptotic probability derivatives and their asymptotic standard errors.

Another point worth noting is that some of the explanatory variables, such as the number of employees, could be viewed as being endogenous. If one had additional data in the temporal or cross sectional dimensions, it would be worthwhile to search for valid instrumental variables. In the present study, this additional information is not available and we treat all the explanatory variables as predetermined. As will be seen below, we have estimated some parsimonious specifications that rely less on the potentially endogenous regressors. Finally, in some runs we encountered problems of singularity of the likelihood function, which necessitated the exclusion of some regressors.

\subsection{Ranking the Highly Rated Constraints}

In Table 2, we present the CEOs' relative rankings of the ten most highly rated constraints. The rows in Table 2 denote constraints, while the entries in the three columns show the number of firms that ranked the given constraint as being (a) the most important one (No. 1), (b) among the three most important constraints (No. 1-3), and (c) among the ten most important constraints (No. 1-10), respectively. ${ }^{8}$ The entries within each column give the five most often cited constraints. Since the number of sampled SOEs in Bulgaria is significant (22), we provide

\footnotetext{
${ }^{8}$ For example, in the row denoted "Production - Suppliers are often not willing to deliver", we observe that in Russia 12 firms identified this constraint as being the most important one and 29 firms cited it as being among the three most severe constraints.
} 
the Bulgarian results separately for private and state-owned firms. In Russia the number of sampled SOEs is small and we therefore provide the results for all firms together.

As may be seen from Table 2, when one considers all firms in both countries, there is a complete overlap across the countries in the five constraints that are most often cited by the CEOs as being (a) the most important constraint (No. 1) or (b) among the three most important constraints (No. 1-3). The most important constraint and the three most important constraints are found most frequently in the areas of production and its expansion, financing, and infrastructure. Within these areas, the specific most important constraints are: "Other production constraints", "suppliers are often not ready to deliver", "financing problems that hinder expanding production", "level of interest rates", and constraints on "getting land, office space and buildings". In both countries, production problems are most frequently cited as the most important constraint but financing problems are most widely cited among the three most important constraints.

When one considers the five constraints that are most often cited by the Russian and Bulgarian firms as being among the ten most important constraints, the two countries maintain an overlap on four constraints, and three of the original five constraints remain in the set. In particular, the "level of interest rates", "financing problems that hinder expanding production" and "getting land, office space and buildings" remain in the set, with the "level of interest rates" being cited most often (by almost one-half of the Russian as well as Bulgarian firms). The new constraint that is common to both countries is "frequent and unpredictable changes in prices of local goods", which is unsurprising given the fact that both countries went through hyperinflation in the early 1990s. This is also the second most frequently cited constraint in both countries. 
"Getting land, office space and buildings" becomes the third most cited constraint in both countries, reflecting the fact that no restitution had taken place in Russia and that legislation restricted the ability to sell restituted land and property in Bulgaria. ${ }^{\text {This is followed by "other }}$ infrastructure constraints" in Bulgaria and "value added taxes" in Russia. Finally, "financing problems that hinder expanding production" comes in fifth in terms of frequency of citations, being cited by slightly more than one-quarter of all Russian and Bulgarian firms. ${ }^{10}$

In view of the above rankings, in the rest of the paper we focus on the constraints in the following four areas: carrying out production, expanding production, financing, and infrastructure.

\subsection{Carrying out Production}

In the area of production, the CEOs were asked to rate eight potential constraints and to identify the most important one among them. ${ }^{\square}$ The main constraints identified by the SMEs in the area of production are "suppliers are often not ready to deliver" (identified as the most important constraint by 33\% Bulgarian and 11\% percent Russian SMEs), "equipment is too old and/or unreliable" (identified as the most important constraint by $25 \%$ of Russian and $8 \%$ of Bulgarian managers), and "other". The first and third among these constraints also appear among the most highly ranked constraints in the overall ranking exercise (Table 2).

\footnotetext{
${ }^{9}$ The inability to sell restituted property affects only private enterprises.

${ }^{10}$ The Bulgarian SOE data show a significant overlap with the private firm rankings when one considers the five constraints that are most often cited as being among the ten most important constraints.

${ }^{11}$ The eight potential constraints included in this area are: (1) Suppliers are often not ready to deliver; (2) Deliveries of raw materials are often delayed due to transport problems; (3) Cannot find spare parts;

(4) Difficult to repair production equipment due to lack of know-how; (5) Equipment is too old and/or unreliable; (6) Lack of skilled manpower; (7) Power shortages; and (8) Other.
} 
Since the CEOs were rating and ranking eight potential constraints, we have estimated a system of eight multinomial logit equations to determine which factors influence the probability that the CEOs select any given constraint as the most important one. In accordance with our conceptual framework, the explanatory variables are the ones listed in section 4.1 and they reflect the characteristics of the entrepreneur, firm and firm's environment.

The estimated derivatives from the logit dealing with the most important constraint, namely "suppliers are often not ready to deliver," are given in Table 3. As may be seen from the table, in Bulgaria one finds a strong relationship between all the explanatory variables and the probability that the constraint "suppliers are often not ready to deliver" is cited as the most important one. The selection of this constraint is negatively related to the (university) education of the manager, the capital intensity of the firm and the extent to which the firm is privately owned. It is positively related to the firm's labor productivity, the percentage of its output in manufacturing and trade, and its size as measured by the number of employees. The probability has a U-shaped relationship with respect to the number of years since the firm acquired its current legal status and the slope is declining within the relevant range for most firms. In Russia, where only 23 firms identified this constraint as the most important one, the only significant coefficients are found with respect to the percentage of output in manufacturing (negative) and the number of employees, which is positive as in Bulgaria.

Hence, while larger firms in both countries appear to be more sensitive to delivery bottlenecks than smaller firms, the similarity ends there. The constraint is for instance more relevant to manufacturing firms in Bulgaria and non-manufacturing ones in Russia, reflecting in 
part the sectoral concentration of de novo firms in the two countries. As we discuss in the Appendix, in Russia relatively more SMEs emerged as a result of unbundling of large manufacturing state-owned enterprises and the manufacturing sector enjoys pre-existing linkages with suppliers and/or parent companies. This makes delivery bottlenecks a less important obstacle for manufacturing SMEs than for those in the service sector which is almost completely composed of de novo firms. In Bulgaria privatization and restructuring had not progressed at the same pace as in Russia and most SMEs, regardless of sectors, are start-ups. Thus the manufacturing sector in Bulgaria does not enjoy the relative advantage that we have observed in Russia. Finally, while the manager's human and the firm's physical capital as well as the age (experience) and private ownership diminish the importance of the delivery constraint in Bulgaria, no systematic relationship with these variables is found in Russia, even in more parsimonious specifications. These differences suggest that the nature of disruption of deliveries after the fall of central planning, discussed by Blanchard and Kremer (1997) and Roland and Verdier (1999), was more ubiquitous and all-encompassing in Russia than in Bulgaria.

As might be expected, the estimated coefficients and calculated derivatives for the seven other constraints listed in the area of production were uniformly insignificant and only the frequently invoked "other" constraint model occasionally produced coefficients whose significance approached the traditional significance test levels. 


\subsection{Expanding Production}

In this area, the managers were asked to rate and identify the most important of eleven potential constraints to expanding production. ${ }^{12}$ In interpreting the answers in this area, it is useful to keep in mind that the average Russian and Bulgarian SME reports to be operating at $57 \%$ and $69 \%$ of production capacity, respectively. In this context, the SME managers identified "financing problems" as constituting the most important constraint. Full 40\% (62\%) of Russian and 29\% (38\%) of Bulgarian managers ranked financing problems as most important (very important). The financing problems also figure prominently in the overall relative ranking of all the most highly rated constraints (Table 2).

Interestingly, when we ran the multinomial logits to assess if there are systematic determinants of the probability that "financing problems" is selected as the most important constraint, we did not obtain significant coefficients in any specification. Hence, the financing problems constraint is important both absolutely and in relative terms, and its effect is uniform in that the probability of its selection is not systematically linked to observable characteristics of the entrepreneur, the firm, or the sector in which the firm operates. 13

\subsection{Financing}

12 The potential obstacles listed in the question are: (1) Competition is high; (2) Not enough qualified labour; (3) Insufficient demand for output; (4) Cannot ship production, bad transportation; (5) I am not interested in expansion; (6) Administrative problems; (7) Input procurement problems; (8) Financing problems; (9) Taxes; (10) Bad access to foreign markets; and (11) Other (specify). 
The SMEs report receiving virtually no open or hidden subsidies from the state. The debt/equity ratio of the average SME was $48 \%$ in Bulgaria and $30 \%$ in Russia, but the mean values have sizable standard deviations. As is the case for SMEs elsewhere in the world, own or family capital played a very important part in the start-up of most of our SMEs. However, bank capital was somewhat important in Bulgaria, and obtaining capital from a spin-off or partners was somewhat important in Russia. This result is in line with the credit rationing literature that is based on the argument of incomplete or asymmetric information (e.g., Jaffee and Stiglitz,1990), according to which younger firms suffer relatively more than older firms from credit rationing. The different pattern in the two countries is also probably brought about by the lack of financial discipline in the Bulgarian financial sector that culminated in the 1996 banking crisis, and by the privatisation pattern in Russia that generated an SME sector that contained relatively more spinoffs. In both countries, the CEOs attribute the willingness of others to lend them at the start of their venture to their personal reputation (cited as most important by $51 \%$ of the CEOs in Russia and $20 \%$ in Bulgaria), ${ }^{4}$ the reputation of their product (20\% and $13 \%$, respectively), and the quality of their business plan (14\% in both countries).

The SMEs in our sample use the banking system in that virtually all (96\% in Bulgaria and 99\% in Russia) have a bank account. However, unlike Johnson, McMillan and Woodruff (1999), we find that the firms' integration into the formal credit system remains limited in both countries. In particular, while most firms in the Johnson, McMillan and Woodruff (1999) sample report receiving a loan, only $37 \%$ of the Bulgarian and $29 \%$ of the Russian firms in our sample report

\footnotetext{
${ }^{13}$ The estimated coefficients of the logits that we ran for the ten other constraints in the area of expanding production were also statistically insignificant.
} 
obtaining a loan from a financial institution in the past three years. ${ }^{-5}$ Moreover, only $56(25 \%)$ of our Bulgarian and $16(7 \%)$ of our Russian firms know about special financing programs for SMEs and only 8 Bulgarian and 7 Russian firms benefited from them.

In this context it is interesting to note that our Russian SMEs on average reinvest $58 \%$ of their profit, while our average Bulgarian SME reinvests $74 \%$ of its profit. These averages are higher than the 30-50\% range reported by Johnson, McMillan and Woodruff (1999). Moreover, while the average firm in all countries of the Johnson, McMillan and Woodruff sample reports non-reinvested profits that exceed its bank loans, in our sample this is the case for Russia but not for Bulgaria. Since in the Russian sample there are more SMEs that are spin-offs resulting from internal buy-outs, it is possible that managers of these firms are not as interested in investing and restructuring as are the owners of the Bulgarian (mostly private start-up) SMEs. This hypothesis that owners of start-up firms have a higher propensity to invest from retained earnings than managers of spin-offs should be explored in future research.

In the area of financing, we asked the managers to rate and identify the most important of

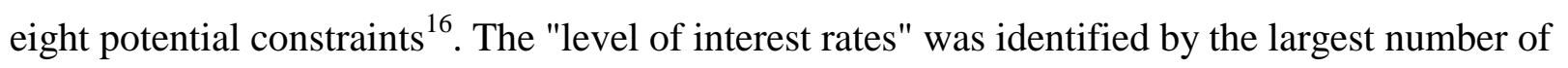

\footnotetext{
${ }^{14}$ In Bulgaria, $46 \%$ of managers did nor rank the most important reason in this question. The $20 \%$ of firms thus correspond to almost $40 \%$ of responding firms.

${ }^{15}$ The difference between Johnson, McMillan and Woodruff's and our results may be explained in part by the fact that their sample covers some of the most developed and wealthy areas of the countries that they investigated (e.g. Katowice in Poland), in part by the high average initial employment of start-ups in their sample (34.4 employees in Poland and 31.9 employees in Ukraine), and in part by their high upper employment limit for private small and medium-sized enterprises (270 vs. 200 employees). The 270 employee limit exceeds even the 250 limit used by the European Union in its official classification. Finally, the Johnson, McMillan and Woodruff surveys were run two-three years after those described in this paper and inevitably reflect a more advanced stage of transition than the one reflected in our survey.

${ }^{16}$ The constraints listed are: Collateral requirements; Requirements to produce financial documents; Level of interest rates; Deposit/loan track record requirement; Not having connections in banks or in 
managers as both a "very important" and the "most important" constraint. Indeed, $83 \%$ of the Russian and $78 \%$ of the Bulgarian managers have rated this constraint as being "very important", and $67 \%$ in each country selected it as the "most important" problem. The level of interest rate is also one of the most highly ranked constraints in the overall ranking of all the highly rated constraints in the questionnaire (Table 2).

When we ran multinomial logits to assess if there were systematic determinants of the probability that the high level of interest rates was selected as the most important constraint, we had to drop several regressors in the Russian equation in order to avoid singularity of the likelihood function and achieve identification. As may be seen from Table 4, in both countries the capital intensity of production has a positive effect on the probability that the level of interest rates is selected as the most important constraint, although in Bulgaria the estimated coefficient is not very significant. The positive coefficient on capital intensity is intuitively plausible as capital-intensive operations have a greater need for investment and suffer more from high interest rates. Unlike in Bulgaria, in Russia we find no other variables affecting significantly the probability that the level of interest rates is selected as the most important constraint by the CEOs. Hence as with the constraint on delivery in production, the interest rate constraint is found to be generally rather than selectively binding in Russia. In contrast, in Bulgaria the probability of selecting interest rates as the most important constraint is also negatively related to the (university) education of the $\mathrm{CEO}$, labor productivity, and in the relevant range also to the age of the firm. It is positively related to the manufacturing orientation of the firm's production, the

financial institutions; Access to non-bank investors/partners; Permits and licenses from institutions other than banks; Other (specify). 
extent to which the firm is privately owned, and its size as measured by employment. These findings indicate that Bulgarian firms that have existed longer and have a more educated manager tend to feel less acutely the interest rate constraint, being probably better able to find a way around this constraint. In contrast, firms that are larger, more capital intensive, operate more in manufacturing (perhaps being perceived by banks as a riskier sector than services) and are more privately (less state-) owned, tend to rank the (high) level of interest rates as being the most important constraint to obtaining financing. These firms need more capital and may have harder time obtaining it from the traditional sources.

\subsection{Infrastructure}

In the area of infrastructure, the CEOs were asked to rate 11 potential constraints and, as usual, to identify the most important one among them. 18 The answers indicate that "getting land,

\footnotetext{
${ }^{17}$ The SMEs not only seek credit but they also serve as creditors. In Russia, about $50 \%$ of the sampled SMEs were asked for credit by their customers in the last two years and about one-third of the firms provided such credit. The corresponding numbers in Bulgaria are 44-47\% and 39-43\%, respectively. Hence about one-third of the Russian and two-fifths of the Bulgarian firms serve as creditors to their customers. This finding is important because it contradicts some of the anecdotal evidence that asymmetric information and high default risk tend to generate a cash-in-advance economy in the transition.

In both countries, virtually all (90\%) firms that provide customer credit personally check the creditworthiness of the buyers, rather than using a credit agency or another mechanism. In both countries they on average finance about one-third of the value of the sales. The average time length of the credit is two months in Russia and 4 months in Bulgaria. The average share of late payments in the total credit has over the last two years been 19-25\% in Russia and 26-27\% in Bulgaria. Defaults have on average accounted for 7-8\% of total credit in Russia and 3-4\% in Bulgaria. SOEs are on average viewed by SME managers to be about $30 \%$ more likely to default than private firms in Russia and more than twice as much likely in Bulgaria. In both countries, the SMEs negotiate with clients that do not pay and some SMEs tend to resort to court or private agency specializing in collection of debts. Very few firms (10 in Russia and 13 in Bulgaria) report writing off debts.

${ }^{18}$ The potential obstacles listed are: (1) Getting land, office space, buildings; (2) Power breakdowns; (3) Voltage fluctuations; (4) Telecommunications problems; (5) Water supply; (6) Waste water disposal; (7) Garbage disposal; (8) Quality of roads; (9) Quality of railway transport; (10) Quality of ports; and (11) Other (specify).
} 
office space and buildings" is the main problem. 52\% of the Russian and 55\% of the Bulgarian managers rated this problem as "very important", while 51\% and 59\%, respectively, ranked it as the "most important" problem in this area. The problem is also identified as one of the most important constraints in the overall ranking across areas of all the highly rated constraints (Table 2). ${ }^{19}$ The ranking is consistent with the fact that leasing land and office space is the dominant mode of operation, with the ratio of SMEs that lease their land and office space to those who own it being 1.7 in Russia and 2.3 in Bulgaria. The finding is intuitively acceptable, given the problems linked to restitution and lack of development of land registries in both countries. The average SME also expressed a strong desire to expand its existing buildings and machinery (by $90 \%$ in Russia and $73 \%$ in Bulgaria), and over two-thirds of the respondents in each country expect to face serious problems in this area.

Table 5 contains the multinomial logit derivatives of the effects of explanatory variables on the probability that "getting land, office space and buildings" is selected as the most important constraint. As may be seen from the table, most of the coefficients are significant for Russia and all are significant for Bulgaria. (As in other estimations, some variables had to be omitted from the system to avoid singularity of likelihood and ensure identification of parameters.) In both countries the probability is negatively related to the age and size of the firm, but positively related to labor productivity. The age effect probably indicates that firms that have been longer in existence either inherited or found ways to secure relatively adequate premises. The size effect may have a similar interpretation, while high productivity could be the result of past growth that

\footnotetext{
${ }^{19}$ Power breakdowns was identified as the most important problem by $18 \%$ of managers in Russia, while telecommunications problems and road quality were each selected by $9 \%$ of the managers in Bulgaria.
} 
moved the firm against the infrastructure constraint. The two countries differ in the effect of CEO's education (positive in Bulgaria and negative in Russia), capital intensity (negative in Bulgaria and insignificant in Russia), percentage of output in manufacturing (positive in Russia but negative in Bulgaria), and the extent of private ownership (insignificant in Russia and positive in Bulgaria). The workings of the emerging real estate market hence appear to be somewhat different in the two countries.

\subsection{Other Issues}

Since specific constraints in the areas of carrying out production and expanding production were identified as most important in Table 2, we have also examined the constraints in the area of sales. The average Russian SME in our sample sells $96 \%$ of its products on the domestic market and reports having done so in the preceding year as well as in the first year of its operations. The average Bulgarian firm is a bit more export-oriented, selling $88 \%$ of its products domestically. $34 \%$ of the Bulgarian and $16 \%$ of the Russian firms changed the markets for which they produced during the last five years. The most highly rated and ranked factor behind this switch was a decline in demand from state institutions, followed by increased opportunities to export to other countries (for Bulgaria) and decreased demand elsewhere in Russia (for the Russian SMEs).

What are the principal obstacles to increasing local sales? To answer this question, we asked the CEOs to rate a list of nine potential constraints and identify the most important one among them ${ }^{20}$. The "lack of credit finance" comes on top, being cited as the most important

${ }^{20}$ The list of potential constraints included: (1) Lack of credit finance; (2) Lack of demand for my products; (3) Competition from local companies; (4) Competition from foreign companies; (5) Technical 
obstacle by $33 \%$ of the Russian and $26 \%$ of the Bulgarian firms. High cost of raw materials is cited by $17 \%$ of the Russian and $25 \%$ of the Bulgarian firms. The principal other constraints (lack of demand, competition from domestic companies, and technological problems) are selected as most important by fewer than $15 \%$ of companies in either country.

In the early phases of the transition, the success of SMEs may depend crucially on their ability to do business with the state sector of the economy. We therefore asked the managers to rate the main obstacles to doing business with the SOEs and other government institutions and to identify the most important constraint. About $30 \%$ of the managers in both countries identified as the most important constraint the fact that "SOEs/government pay late or less than the agreed amounts". $25 \%$ of managers in both countries ranked as the most important constraint the fact that "contracts are only available to those with connections". These two constraints were also rated more frequently than others as being very important constraints in this area. The results suggest that the SOEs and government institutions discriminate or project the image that they discriminate against SMEs in allocating contracts, and also that delinquency in payments makes it difficult for SMEs to do business with the state sector. The findings are surprisingly uniform across the two countries and appear to be consistent with the more casual evidence from other transition economies.

or technological problems; (6) Difficulties with supplies; (7) High cost of raw materials; (8) Lack of skilled labour; and (9) Other (specify). 
In identifying obstacles to increasing exports, we asked the CEOs to rate a list of constraints and to identify the most important one among them 21 . The lack of finance was again cited as the most important constraint to starting or increasing exports. Indeed $41 \%$ of the Russian and 18\% of Bulgarian firms identified this as the most important constraint, with the Bulgarian percentage constituting over 30\% of responses since $40 \%$ of the Bulgarian SMEs did not identify the most important constraint in this area.

The multinomial logits that we ran show that few significant relationships exist with our explanatory variables in Bulgaria, but very definite patterns may be established for the lack of finance in Russia. In the Bulgarian data, one finds that firms with higher sales per employee are less likely to cite "a lack of finance" and more privately owned firms are less likely to identify "competition in new markets" as the most important constraint. In Russia the lack of finance is positively and significantly related to all the explanatory variables except for the size of the firm, where the relationship is negative and significant.

The two areas that SME managers did not identify as having severe constraints are government regulation and business services. In this context, it is interesting to note that the firms do not report being constrained by the difficulty of obtaining licenses or facing security issues. ${ }^{2}$ However, since licensing affects disproportionately nascent businesses, our finding of a

21 The list of potential constraints includes: Lack of finance; Lack of knowledge of new markets; Lack of new technology; Competition in new markets; Administrative costs (tariffs, licenses) necessary for export; Lack of skilled labour; Other (specify).

22 The average firm in our sample needed 2 licenses in Russia and 3 in Bulgaria to start operations. It spent 208 hours in Russia and 164 hours in Bulgaria and waited 6.7 and 5 weeks, respectively, to obtain these licenses. $10 \%$ of the Russian and $25 \%$ of the Bulgarian firms hired external agents to help them obtain start-up licenses. Two-thirds of the Bulgarian but only $44 \%$ of the Russian firms employ a security company or individuals for protecting their premises. 
lack of major constraint in this area probably underestimates the seriousness of the issue. In particular, our sample excludes those entrepreneurs who did not succeed in starting business due to the complexity and burden of government regulation. This may be a serious issue that we are unable to register in our data.

\section{Conclusions}

Our study of stratified random samples of 216 Russian and 221 Bulgarian small and medium size enterprises (SMEs) shows a remarkable similarity of views of their owners/top managers (CEOs) with respect to objectives and constraints that they face. This finding suggests that the nature of issues confronting SMEs and the policies that may be formulated to assist them are similar across the transition economies. The CEO responses and data from their firms yield the following specific conclusions:

A. The SMEs in the two economies are primarily recently created and privately owned firms that are characterized by highly concentrated ownership. The two most important objectives of their CEOs are achieving the highest possible profit and output growth. While for new and small firms these two objectives may represent the same goal, the emphasis on output growth may also signal the presence of obstacles to growth. In the future, researchers ought to examine in depth these two competing explanations. Resolving this issue is important from both the academic and policy standpoint.

B. Most CEOs in both countries perceive to be hampered by a relatively small number of specific constraints. The five constraints that they cite most frequently as being most

There is thus a much greater reliance by the Russian SMEs on in-house protection than is the case in Bulgaria. 
important in both countries are: (i) "suppliers are often not ready to deliver", (ii) the firm is facing "financing problems that hinder expanding production", (iii) the firm is facing high "level of interest rates", (iv) the firm is facing constraints on "getting land, office space and buildings", and (v) "other production constraints".

C. Constraints on obtaining external financing and the high cost of this financing are hence two of the top five constraints cited by most CEOs. The lack of credit finance was also cited by the CEOs as being the most important obstacle to increasing local sales, and it also appeared as the most important constraint with respect to increasing exports. Moreover, the constraint appears to be binding across the board, since the probability of it being selected as the most important constraint to expanding production is unrelated to manager-, firm- or sectorspecific variables. Finally, only about a third of the surveyed firms report receiving a loan from a financial institution over the past three years and an even smaller fraction have heard about special financing programs for SMEs. Our principal finding is hence that the external financing constraint is a serious one. We also find that firms reinvest profits while operating under the external financing constraint. We hence conclude that financial constraints hamper SME growth and that the use of internal finance by SMEs represents a fall-back option. In this sense our study provides evidence that is contrary to the findings of Johnson, McMillan and Woodruff (1999). Our evidence is consistent, however, with the findings of Rajan and Zingales (1998), Winker (1999) and Lizal and Svejnar (2000).

D. Our econometric analysis of the determinants of the most important constraints indicate that all three sets of factors (characteristics of the entrepreneur, of the firm and of the firm's 
environment) are important. However, their effect is not always uniform across countries and constraints. For example, more educated entrepreneurs are better able to ensure that suppliers deliver and in Bulgaria they are also better able to get around the problem of high interest rates. Firm-specific factors are found to be important in that larger size firms for instance suffer more from unreliable supplier deliveries, capital intensive firms complain more about the problem of high interest rates and more established (older) and larger firms are better able to cope with problems of getting land, office space and buildings. Environmental factors, which we capture by the sectoral location of the firm, are important but their effect often differs in the two economies. In Bulgaria, firms in manufacturing suffer more than other firms from supplier delivery problems, while the situation is reverse in Russia. Yet, in Russia manufacturing firms suffer more than others from the problem of getting land, office space and buildings, while the situation is just the opposite in Bulgaria. Finally, we find that the most important constraints in the areas of production and finance are all-encompassing in Russia in that they affect SMEs irrespective of the characteristics of the CEO, the firm, or the sector of activity. In contrast, in Bulgaria the severity of the most important constraints in these two areas varies systematically with the $\mathrm{CEO}$, firm and sectoral characteristics. These differences suggest that the nature of disruption of production and of the financial constraints after the fall of central planning was more ubiquitous and all-encompassing in Russia than in Bulgaria. Hence, our empirical evidence is consistent with the hypothesis that the disorganization phenomenon modelled for instance by Blanchard and Kremer (1997) and 
Roland and Verdier (1999) was more prevalent in the former Soviet Union than in the satellite countries of Central and Eastern Europe.

E. Finally, while SMEs would clearly benefit in their development if they had fair access to doing business with the state sector, our findings indicate that the state firms and other government institutions discriminate or project the image that they discriminate against SMEs in allocating contracts. Moreover, the state's delinquency in making payments for goods delivered and services rendered makes it difficult for the financially strapped SMEs to do business with the state sector. 


\section{References}

Ben-Ner, A., J. M. Montias, and E. Neuberger (1993), "Basic Issues in Organizations: A Comparative Perspective," Journal of Comparative Economics, 17(2), June, 207-242.

Blanchard, O. and M. Kremer (1997), “Disorganization,” Quarterly Journal of Economics, 112(4), 1091-1126.

Bonin, J., D. Jones, and L. Putterman (1993), Theoretical and Empirical Studies of Producer Cooperatives: Will Ever the Twain Meet?, Journal of Economic Literature; 31(3), September 1993, pages 1290-320.

EBRD (1993), Transition Report 1993, London: EBRD.

Eurostat (1998), Enterprises in Europe, Fifth Report. Data 1994-95, Luxwmbourg, European Commission.

Fischer, S., R. Sahay and C Vegh (1996), "Stabilization and Growth in Transition Economies: The Early Experience," Journal of Economic Perspectives, 10(2), Spring, 45-66.

Gomulka (1994), Obstacles to recovery in Transition Economies, in P.Aghion and N.Stern (eds.), "Obstacles to Enterprise Restructuring in Transition", EBRD Working Paper, No 16.

Hart, O. and J. Moore (1990), "Property Rights and the Nature of the Firm," Journal of Political Economy, 98(5), Sept-Oct., 1119-1158.

Hurwicz, L. (1973), “The Design of Mechanisms for Resource Allocation,” American Economic Review, 63(1), March, 1-30.

Jaffee, D and J. Stiglitz (1990), “Credit Rationing," Handbook of Monetary Economics, Vol. 2 and Handbooks in Economics, No. 8, 837-888.

Johnson, McMillan and Woodruff (1999), "Property Rights, Finance, and Entrepreneurship," , EBRD Working Paper, No 43.

Levine, R. (1997), "Financial Development and Economic Growth: Views and Agenda," Journal of Economic Literature, 35(2), June, 688-726.

Lizal, L. and J. Svejnar (2000), "Investment, Credit Rationing and the Soft Budget Constraint: Evidence from Czech Panel Data," Working Paper No. 60b, The William Davidson Institute at the University of Michigan Business School, Revised, April. 
Milgrom, P. and J. Roberts (1990), "The Economics of Modern Manufacturing: Technology, Strategy, and Organization,” American Economic Review, 80(3), June, 511-528.

Rajan, R. and L. Zingales (1998), "Financial Dependence and Growth," American Economic Review, 88(3), June, 559-586.

Roland, G. and T. Verdier (1999), "Transition and the Output Fall," Economics of Transition, $7(1), 1-28$

Williamson, O. (1985), The Economic Institutions of Capitalism: Firms, Markets, Relational Contracting, New York: Free Press/Collier Macmillan.

Winker, P (1999), Causes And Effects Of Financing Constraints At The Firm Level, Small Business Economics, vol. 12, No 2, March 1999.

Zemplinerova, A. and J. Stibal (1995), "Evolution and Efficiency of Concentration in Manufacturing," Chapter 11 in J. Svejnar ed., The Czech Republic and Economic Transition in Eastern Europe, San Diego, CA: Academic Press. 


\section{Appendix}

\section{Basic Statistics}

The two samples are of similar size, comprising 216 companies in Russia and 221 in

Bulgaria 23 As may be seen from Table A1, they contain primarily private companies. In both Bulgaria and Russia, most private SMEs are individual or family owned, followed by local private ownership. Unsurprisingly, given the tendency of FDI to concentrate in larger firms, very few of the sampled SMEs have foreign owners. Moreover, in virtually all firms the principal owner has a majority ownership, with the average ownership being in excess of $90 \%$ and having low standard deviation in most ownership categories.

Table A2 shows the relationship between the current and former ownership status of the firm. As may be seen from the table, an overwhelming majority of the sampled companies (73\% in Russia and $82 \%$ in Bulgaria) started as a new company. The concentration of start-ups is even higher if the sample is restricted to private sector only (79\% of Russian SMEs and $92 \%$ of the Bulgarian SMEs). ${ }^{24}$ The fact that relatively more Bulgarian companies are new start-ups of course reflects the different privatisation pattern the two countries. Whereas in the case of smallscale privatisation both countries had progressed more or less at the same pace, at the time Russia had advanced well with large-scale privatisation and unbundling of large state owned companies relatively to Bulgaria, thus generating a greater proportion of spin-offs in its SME sector. Bulgaria instead experienced significant resistance to large-scale privatisation from both

\footnotetext{
${ }^{23}$ The response rate was high and most of our findings are based on responses from all or virtually all of the firms.

${ }^{24}$ As can be seen from Table A2, these percentages actually underestimate the numbers of private companies that started private. This is because some companies report to have always been private. When these "old"
} 
ministry officials and management of state enterprises and virtually no restructuring. Thus the impetus to private sector development in that country found its outlet in the creation of new companies. This is reflected in the sample, with full $18 \%$ of the Russian companies but only $4 \%$ of the Bulgarian SMEs report to have existed as part of a state-owned enterprise before.

Since most of the surveyed SMEs started as a new company, it is not surprising to find that the companies are fairly young. The average Bulgarian SME started its operations in 1989 and obtained its current legal status in 1991. The average Russian SME started operating in 1986 and its current legal status dates to 1992. An examination of the data indicates that the number of years since obtaining the current legal form is more indicative of the experience of the firm and its current management than the founding date because some firms report the founding dates of companies from which they were spun off.

Virtually all the SMEs (96\% in Russia and 98\% in Bulgaria) are independent companies rather than subsidiaries. In terms of corporate structure, one can see from Table A3 that most Russian and Bulgarian SMEs are registered as limited liability companies or partnerships. In Bulgaria, over one-third are registered as unlimited liability companies, indicating lesser concern of the Russian SMEs about limiting their liability exposure. In Russia a bankruptcy law became effective in March 1993 and, despite its limited implementation, it had started to influence enterprise behaviour (EBRD, 1995). In Bulgaria the 1994 bankruptcy law started being

private companies are added to the "newly formed" private companies, the percentage of private firms that started as private is $95 \%$ in Bulgaria and $81 \%$ in Russia.

${ }^{25}$ This difference is not brought about by relatively more Russian non-private firms reporting that they were part of an SOE in the past. Rather, 14\% of the Russian private firms but only $3 \%$ of the Bulgarian private firms report to have been part of an SOE. 
implemented only in the second half of 1996 (EBRD, 1996), well after the administration of this survey.

The summary statistics of the main variables, reported in Table A4, indicate that the average private SME is roughly of a similar size in the two countries, having 27 employees in Bulgaria and 33 in Russia. The average private Bulgarian SME has a higher labor cost to sales ratio and a correspondingly lower profit to sales ratio than its Russian counterpart. The average figures for the state firms (especially in Russia) are not particularly useful because of a significant skewness in the distribution of the various values. Nevertheless, it is useful to note that in both countries the average SOE is much larger (in terms of employment) than the corresponding average private firm. While one might a priori expect the SMEs to engage in labor intensive operations, in both samples the average ratio of labor cost to total cost is just under $20 \%$. With the average reported profit amounting to somewhat more than the labor cost in Russia and slightly less than the labor cost in Bulgaria, there is evidence that non-labor inputs are a crucial component of costs for these firms. 
Table 1: Importance Placed by the CEO on Various Objectives

\begin{tabular}{|c|c|c|c|c|c|c|c|c|c|c|c|c|c|c|c|c|}
\hline & \multicolumn{4}{|c|}{ Russia - All Firms } & \multicolumn{4}{|c|}{ Russia - Private Firms } & \multicolumn{4}{|c|}{ Bulgaria - All Firms } & \multicolumn{4}{|c|}{ Bulgaria Private Firms } \\
\hline & \multicolumn{2}{|c|}{$\begin{array}{c}\text { Very } \\
\text { Important }^{1}\end{array}$} & \multicolumn{2}{|c|}{$\begin{array}{c}\text { Most } \\
\text { Important }^{2}\end{array}$} & \multicolumn{2}{|c|}{$\begin{array}{c}\text { Very } \\
\text { Important }^{1}\end{array}$} & \multicolumn{2}{|c|}{$\begin{array}{c}\text { Most } \\
\text { Important }^{2}\end{array}$} & \multicolumn{2}{|c|}{$\begin{array}{c}\text { Very } \\
\text { Important }^{1}\end{array}$} & \multicolumn{2}{|c|}{$\begin{array}{c}\text { Most } \\
\text { Important }^{2}\end{array}$} & \multicolumn{2}{|c|}{$\begin{array}{c}\text { Very } \\
\text { Important }^{1}\end{array}$} & \multicolumn{2}{|c|}{$\begin{array}{c}\text { Most } \\
\text { Important }^{2}\end{array}$} \\
\hline & $\mathrm{N}$ & $\%$ & $\mathrm{~N}$ & $\%$ & $\mathrm{~N}$ & $\%$ & $\mathrm{~N}$ & $\%$ & $\mathrm{~N}$ & $\%$ & $\mathrm{~N}$ & $\%$ & $\mathrm{~N}$ & $\%$ & $\mathrm{~N}$ & $\%$ \\
\hline $\begin{array}{l}\text { Achieve Highest } \\
\text { Possible Output }\end{array}$ & 154 & 71 & 82 & 38 & 136 & 72 & 73 & 39 & 158 & 72 & 114 & 52 & 138 & 73 & 101 & 54 \\
\hline $\begin{array}{l}\text { Achieve Highest } \\
\text { Possible Profit }\end{array}$ & 153 & 71 & 106 & 49 & 134 & 71 & 93 & 49 & 96 & 44 & 56 & 26 & 84 & 45 & 50 & 27 \\
\hline $\begin{array}{l}\text { Achieve Highest } \\
\text { Possible Wages }\end{array}$ & 87 & 40 & 13 & 6 & 72 & 38 & 10 & 5 & 57 & 26 & 11 & 5 & 48 & 26 & 10 & 5 \\
\hline $\begin{array}{l}\text { Achieve Highest } \\
\text { Possible Employment }\end{array}$ & 47 & 22 & 3 & 1 & 42 & 22 & 3 & 2 & 21 & 10 & 3 & 1 & 19 & 10 & 2 & 1 \\
\hline $\begin{array}{l}\text { Achieve Highest } \\
\text { Possible Non-wage Benefits }\end{array}$ & 33 & 15 & 2 & 1 & 26 & 14 & 2 & 1 & 30 & 14 & 1 & .5 & 20 & 11 & 1 & .5 \\
\hline $\begin{array}{l}\text { Prepare Privatization } \\
\text { (If SOE) }\end{array}$ & 9 & 4 & 0 & 0 & - & - & - & - & 5 & 2 & 5 & 2 & - & - & - & - \\
\hline Prevent Social Conflict & 59 & 27 & 4 & 2 & 51 & 27 & 4 & 2 & 16 & 7 & 3 & 1 & 13 & 7 & 2 & 1 \\
\hline Other Objective & 15 & 7 & 4 & 2 & 13 & 7 & 3 & 2 & 36 & 16 & 20 & 10 & 27 & 14 & 17 & 9 \\
\hline Not Answered & 0 & & 2 & 1 & 0 & & 1 & & 0 & & 5 & 2 & 0 & & 5 & 3 \\
\hline Total & 557 & & 216 & 100 & 474 & & 189 & 100 & 419 & & 219 & 100 & 349 & & 188 & 100 \\
\hline
\end{tabular}

Note: ${ }^{1}$ Gives the numbers and percentage of firms that considered (rated) a given objective as very important, where very important equals 5 on a scale from 1 (unimportant) to 5. More than one objective could be rated very important.

${ }^{2}$ Gives the number and percentage of firms that ranked a given objective as the most important from all the objectives. 
Table 2: Relative Ranking of Most Highly Rated Constraints -

Number of Firms Ranking a Given Constraint as No. 1, No. 1-3 and No. 1-10

(Results Based on 5 Most Often Cited Constraints)

\begin{tabular}{|c|c|c|c|c|c|c|c|c|c|}
\hline & \multicolumn{3}{|c|}{$\begin{array}{c}\text { Russia } \\
(\mathrm{N}=216)\end{array}$} & \multicolumn{3}{|c|}{$\begin{array}{l}\text { Bulgaria Private } \\
\qquad(\mathrm{N}=190)\end{array}$} & \multicolumn{3}{|c|}{$\begin{array}{l}\text { Bulgaria State } \\
(\mathrm{N}=22)\end{array}$} \\
\hline & No. 1 & No. $1-3$ & No. $1-10$ & No. 1 & No. $1-3$ & No. $1-10$ & No. 1 & No. $1-3$ & No. $1-10$ \\
\hline \multicolumn{10}{|l|}{ Constraints: } \\
\hline \multicolumn{10}{|l|}{ Production } \\
\hline - Suppliers are often not ready to deliver & 12 & 29 & & 11 & 27 & & 1 & & \\
\hline - Equipment is too old or unreliable & & & & & & & 1 & 4 & \\
\hline - Other & 26 & 33 & & 22 & 29 & & 4 & 4 & \\
\hline \multicolumn{10}{|l|}{ Expanding Production } \\
\hline - Financing Problems & 15 & 35 & 58 & 14 & 32 & 50 & & & 7 \\
\hline - Taxes & & & & & & & & 3 & \\
\hline - Bad access to foreign markets & & & & & & & & 3 & \\
\hline \multicolumn{10}{|l|}{ Financing } \\
\hline - Level of Interest Rates & 18 & 38 & 101 & 16 & 34 & 89 & & & 7 \\
\hline \multicolumn{10}{|l|}{ Infrastructure } \\
\hline $\begin{array}{l}\text { - Getting land, office space, buildings } \\
\text { - Other }\end{array}$ & 11 & 25 & 79 & 11 & 24 & $\begin{array}{l}75 \\
58\end{array}$ & & & \\
\hline \multicolumn{10}{|l|}{ Local Purchases } \\
\hline $\begin{array}{l}\text { - Prices of local goods change in a frequent and } \\
\text { unpredictable manner }\end{array}$ & & & 80 & & & 69 & & 3 & 8 \\
\hline \multicolumn{10}{|l|}{ Taxes } \\
\hline - Value Added Taxes & & & 66 & & & & & & \\
\hline - Other & & & & & & & & & 7 \\
\hline \multicolumn{10}{|l|}{ Regulation } \\
\hline - Trade Unions & & & & & & & 2 & & \\
\hline \multicolumn{10}{|l|}{ Imports } \\
\hline - Prices of imported goods are too high & & & & & & & 1 & & 6 \\
\hline
\end{tabular}


Table 3: Determinants of the Probability that the Most Important Constraint in the Area of Production is "Suppliers Are Not Ready to Deliver,"

(Multinomial Logit Estimates of Probability Derivatives;

Values in Parentheses are Asymptotic Standard Errors)

\begin{tabular}{|c|c|c|}
\hline & Russia & Bulgaria \\
\hline Constant & $\begin{array}{c}.092 \\
(.145)\end{array}$ & $\begin{array}{c}-.556 * * \\
(.180)\end{array}$ \\
\hline University Education & $\begin{array}{l}-.033 \\
(.040)\end{array}$ & $\begin{array}{c}-.076 * * \\
(.026)\end{array}$ \\
\hline Age of Firm & $\begin{array}{l}-.256 \\
(.286)\end{array}$ & $\begin{array}{c}-1.424 * * \\
(.504)\end{array}$ \\
\hline$(\text { Age of Firm })^{2}$ & $\begin{array}{c}.575 \\
(.428)\end{array}$ & $\begin{array}{l}.022 * * \\
(.008)\end{array}$ \\
\hline$(\mathrm{Q} / \mathrm{L}) / 1000$ & $\begin{array}{c}.0004 \\
(.0004)\end{array}$ & $\begin{array}{l}.064 * * \\
(.022)\end{array}$ \\
\hline$(\mathrm{K} / \mathrm{L}) / 1000$ & $\begin{array}{c}.001 \\
(.001)\end{array}$ & $\begin{array}{c}-.199 * * \\
(.068)\end{array}$ \\
\hline$\% \mathrm{Q}$ in Manufacturing & $\begin{array}{l}-.002 * \\
(.001)\end{array}$ & $\begin{array}{l}.012 * * \\
(.004)\end{array}$ \\
\hline$\% \mathrm{Q}$ in Trade & $\begin{array}{l}-.0005 \\
(.0019)\end{array}$ & $\begin{array}{l}.014 * * \\
(.005)\end{array}$ \\
\hline$\%$ Private Ownership & $\begin{array}{c}.0005 \\
(.0005)\end{array}$ & $\begin{array}{c}-.0016 * * \\
(.0006)\end{array}$ \\
\hline No. Of Employees/1000 & $\begin{array}{c}1.55 * * \\
(.71)\end{array}$ & $\begin{array}{l}.919 * * \\
(.315)\end{array}$ \\
\hline P Value & .000 & .048 \\
\hline
\end{tabular}

Notes: $\quad$ P value for the Wald test that all parameters are jointly zero.

$* \quad=\quad$ Significantly different from zero at $10 \%$ test level.

$* * \quad=\quad$ Significantly different from zero at $5 \%$ test level. 
Table 4: Determinants of the Probability that the Most Important Constraint in the Area of Financing is the "Level of Interest Rates"

(Multinomial Logit Estimates of Probability Derivatives; Values in Parentheses are Asymptotic Standard Errors)

\begin{tabular}{lcc}
\hline & Russia & Bulgaria \\
\hline Constant & $.333^{* *}$ & $.472^{* *}$ \\
& $(.092)$ & $(.037)$ \\
University Education & -.028 & $-.027 * *$ \\
& $(.067)$ & $(.002)$ \\
Age of Firm & -.079 & $-.747 * *$ \\
& $(.203)$ & $(.059)$ \\
$(\text { Age of Firm })^{2}$ & & $.010^{* *}$ \\
(Q/L)/1000 & & $(.001)$ \\
(K/L)/1000 & .0002 & $-.020 * *$ \\
& $(.0031)$ & $(.002)$ \\
\% Q in & $.006 * *$ & .134 \\
Manufacturing/1000 & $(.003)$ & $(.010)$ \\
P Private Ownership & & $.131 * *$ \\
No. of Employees & & $(.013)$ \\
& & $.001 * *$ \\
& & $(.0001)$ \\
& & $.003 * *$ \\
& & $(.0003)$ \\
& & 0.000 \\
\hline
\end{tabular}

Notes: $\mathrm{P}$ value for the Wald test that all parameters are jointly zero.

$* \quad=\quad$ Significantly different from zero at $10 \%$ test level.

$* * \quad=\quad$ Significantly different from zero at $5 \%$ test level or better. 
Table 5: Determinants of the Probability that the Most Important Problem in the Area of Infrastructure is "Getting Land, Office Space and Buildings"

(Multinomial Logit Estimates of Probability Derivatives; Values in

Parentheses are Asymptotic Standard Errors)

\begin{tabular}{|c|c|c|}
\hline & Russia & Bulgaria \\
\hline Constant & $\begin{array}{c}.395 * * \\
(.116)\end{array}$ & $\begin{array}{c}.038 \\
(.025)\end{array}$ \\
\hline Apprenticeship Education & & $\begin{array}{l}.081 * * \\
(.014)\end{array}$ \\
\hline University Education & $\begin{array}{c}-.097 * * \\
(.029)\end{array}$ & $\begin{array}{l}.254 * * \\
(.031)\end{array}$ \\
\hline Age of Firm & $\begin{array}{c}-.754 * * \\
(.270)\end{array}$ & $\begin{array}{c}-.375^{* *} \\
(.096)\end{array}$ \\
\hline (Age of Firm) & $\begin{array}{c}.431 \\
(.354)\end{array}$ & $\begin{array}{l}.011 * * \\
(.002)\end{array}$ \\
\hline$(\mathrm{Q} / \mathrm{L}) / 1000$ & $\begin{array}{l}.0012 * * \\
(.0005)\end{array}$ & $\begin{array}{l}.018 * * \\
(.006)\end{array}$ \\
\hline$(\mathrm{K} / \mathrm{L}) / 1000$ & $\begin{array}{c}.0008 \\
(.0008)\end{array}$ & $\begin{array}{c}-.091 * * \\
(.015)\end{array}$ \\
\hline$\% \mathrm{Q}$ in Manufacturing/1000 & $\begin{array}{c}1.865 * * \\
(.846)\end{array}$ & $\begin{array}{c}-.318 * * \\
(.157)\end{array}$ \\
\hline$\% \mathrm{Q}$ in Trade & $\begin{array}{c}.0034 * * \\
(.0015)\end{array}$ & \\
\hline$\%$ Private Ownership & $\begin{array}{l}-.0006 \\
(.0005)\end{array}$ & $\begin{array}{l}.003 * * \\
(.0004)\end{array}$ \\
\hline No. Of Employees & $\begin{array}{c}-.0027 * * \\
(.0005)\end{array}$ & $\begin{array}{c}-.0015 * * \\
(.0002)\end{array}$ \\
\hline P Value & 0.000 & 0.000 \\
\hline
\end{tabular}

Notes: P value for the Wald test that all parameters are jointly zero.

$* \quad=\quad$ Significantly different from zero at $10 \%$ test level.

$* *=$ Significantly different from zero at $5 \%$ test level or better. 
Table A1: Ownership of SMEs

\begin{tabular}{|c|c|c|c|c|}
\hline & \multicolumn{2}{|c|}{ Russia } & \multicolumn{2}{|c|}{ Bulgaria } \\
\hline & Number & $\%$ & Number & $\%$ \\
\hline Private & 189 & 87.5 & 190 & 86 \\
\hline State Owned & 7 & 3.2 & 22 & 10 \\
\hline $\begin{array}{l}\text { Mixed Form } \\
\text { (Joint Venture) }\end{array}$ & 16 & 7.4 & 7 & 3.1 \\
\hline Other & 4 & 1.9 & 2 & 0.9 \\
\hline Total & 216 & 100 & 221 & 100 \\
\hline
\end{tabular}


Table A2: Evolution of Ownership of SMEs

\begin{tabular}{|c|c|c|c|c|c|c|c|c|c|c|c|}
\hline & \multicolumn{5}{|c|}{ Russia } & \multicolumn{6}{|c|}{ Bulgaria } \\
\hline & \multicolumn{2}{|c|}{ All Firms } & \multicolumn{2}{|c|}{ Now Private } & \multirow{2}{*}{$\frac{\text { Now State }}{\mathrm{N}}$} & \multicolumn{2}{|c|}{ All Firms } & \multicolumn{2}{|c|}{ Now Private } & \multicolumn{2}{|c|}{ Now State } \\
\hline & $\mathrm{N}$ & $\%$ & $\mathrm{~N}$ & $\%$ & & $\mathrm{~N}$ & $\%$ & $\mathrm{~N}$ & $\%$ & $\mathrm{~N}$ & $\%$ \\
\hline Formed as a new Co. & 158 & 73 & 150 & 79.4 & 2 & 181 & 81.9 & 175 & 92.1 & - & - \\
\hline Was Part of a SOE & 39 & 18 & 27 & 14.3 & 2 & 8 & 4.0 & 6 & 3.1 & 2 & 9.1 \\
\hline Was Part of a Private Co. & 5 & 2.3 & 4 & 2.1 & - & 3 & 1.4 & 3 & 1.6 & - & - \\
\hline Was Part of a Coop & 5 & 2.3 & 3 & 1.6 & - & - & - & - & - & - & - \\
\hline Has always been a SOE & 4 & 1.9 & - & - & 2 & 22 & 10 & - & - & 20 & 90.9 \\
\hline Has always been a Private Co. & 3 & 1.4 & 3 & 1.6 & - & 6 & 2.7 & 6 & 3.2 & - & - \\
\hline Other & 2 & 0.9 & 2 & 1.1 & - & - & - & - & - & - & - \\
\hline Total & 216 & 100 & 189 & 100 & 6 & 221 & 100 & 190 & 100 & 22 & 100 \\
\hline
\end{tabular}

Notes: Percentages in columns will not add up due to rounding off. 
Table A3: Corporate Structure of SMEs

\begin{tabular}{|c|c|c|c|c|}
\hline & \multicolumn{2}{|c|}{ Russia } & \multicolumn{2}{|c|}{ Bulgaria } \\
\hline & $\mathrm{N}$ & $\%$ & $\mathrm{~N}$ & $\%$ \\
\hline Ltd. Liability & 34 & 15.7 & 86 & 38.9 \\
\hline Unlimited Liability & - & - & 81 & 36.7 \\
\hline Ltd. Partnership & 113 & 52.3 & 1 & 0.5 \\
\hline General Partnership & - & - & 40 & 18.1 \\
\hline Joint Stock & 27 & 12.5 & 8 & 3.6 \\
\hline State Enterprise & 3 & 1.4 & 4 & 1.8 \\
\hline Producer Cooperative & 4 & 1.9 & - & - \\
\hline Municipal Enterprise & 3 & 1.4 & - & - \\
\hline Other & 32 & 14.8 & 1 & 0.5 \\
\hline Total & 216 & 100 & 221 & 100 \\
\hline
\end{tabular}


Table A4: Mean Values of Statistics Relating to Enterprise Structure and Performance

\begin{tabular}{|c|c|c|c|c|}
\hline & \multicolumn{2}{|c|}{ Russia (1995) } & \multicolumn{2}{|c|}{ Bulgaria (1994) } \\
\hline & $\begin{array}{c}\text { Private } \\
(\mathrm{N}=187)\end{array}$ & $\begin{array}{l}\text { SOEs } \\
(\mathrm{N}=7)\end{array}$ & $\begin{array}{c}\text { Private } \\
(\mathrm{N}=180)\end{array}$ & $\begin{array}{c}\text { SOEs } \\
(\mathrm{N}=20)\end{array}$ \\
\hline Sales & 760.7 & 628.6 & 14,872 & 14,872 \\
\hline Total Cost & 565.2 & 239.0 & 10,312 & 22,929 \\
\hline Labor Cost & 92.2 & 62.7 & 2,961 & 4,074 \\
\hline Pretax Profit & 114.3 & 35.4 & 1,204 & 2,343 \\
\hline Fixed Assets & 300.1 & 599.6 & 4,292 & 23,675 \\
\hline Total Employment & 33.0 & 52.6 & 27.3 & 74.5 \\
\hline Full-time Employment & 29.7 & 51.7 & 23.7 & 72.7 \\
\hline Part-time Employment & 1.4 & .9 & .74 & .1 \\
\hline Casual Employment & 1.8 & 0 & 2.8 & 1.7 \\
\hline
\end{tabular}




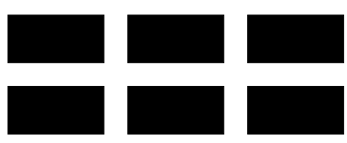

THE WILLIAM DAVIDSON INSTITUTE

AT THE UNIVERSITY OF MICHIGAN BUSINESSSCHOOL

\section{DAVIDSON INSTITUTE WORKING PAPER SERIES}

CURRENT AS OF 11/06/00

\begin{tabular}{|c|c|c|}
\hline Publication & Authors & Date of Paper \\
\hline $\begin{array}{l}\text { No. } 346 \text { Objectives and Constraints of } \\
\text { Entrepreneurs: Evidence from Small and } \\
\text { Medium Size Enterprises in Russia and } \\
\text { Bulgaria }\end{array}$ & $\begin{array}{l}\text { Francesca Pissarides, Miroslav Singer and } \\
\text { Jan Svejnar }\end{array}$ & October 2000 \\
\hline $\begin{array}{l}\text { No. } 345 \text { Corruption and Anticorruption in the } \\
\text { Czech Republic }\end{array}$ & Lubomír Lízal and Evžen Kočenda & October 2000 \\
\hline $\begin{array}{l}\text { No. } 344 \text { The Effects of Direct Foreign } \\
\text { Investment on Domestic Firms }\end{array}$ & Jozef Konings & October 2000 \\
\hline $\begin{array}{l}\text { No. } 343 \text { On the Identification of Relative } \\
\text { Wage Rigidity Dynamics }\end{array}$ & Patrick A. Puhani & October 2000 \\
\hline $\begin{array}{l}\text { No. } 342 \text { The Determinants of Foreign Direct } \\
\text { Investment in Transition Economies }\end{array}$ & Alan A. Bevan and Saul Estrin & October 2000 \\
\hline $\begin{array}{l}\text { No. } 341 \text { The Global Spread of Stock } \\
\text { Exchanges, } 1980-1998\end{array}$ & Klaus Weber and Gerald F. Davis & October 2000 \\
\hline $\begin{array}{l}\text { No. } 340 \text { The Costs and Benefits of Euro- } \\
\text { isation in Central-Eastern Europe Before or } \\
\text { Instead of EMU Membership }\end{array}$ & D. Mario Nuti & October 2000 \\
\hline No. 339 Debt Overhang and Barter in Russia & $\begin{array}{l}\text { Sergei Guriev, Igor Makarov and Mathilde } \\
\text { Maurel }\end{array}$ & September 2000 \\
\hline $\begin{array}{l}\text { No. } 338 \text { Firm Performance and the Political } \\
\text { Economy of Corporate Governance: Survey } \\
\text { Evidence for Bulgaria, Hungary, Slovakia and } \\
\text { Slovenia }\end{array}$ & Patrick Paul Walsh and Ciara Whela & July 2000 \\
\hline No. 337 Investment and Instability & Nauro F. Campos and Jeffrey B. Nugent & May 2000 \\
\hline $\begin{array}{l}\text { No. } 336 \text { The Evolution of the Insurance } \\
\text { Sector in Central and Eastern Europe and } \\
\text { the former Soviet Union }\end{array}$ & Robert B.K. Pye & August 2000 \\
\hline $\begin{array}{l}\text { No. } 335 \text { Institutional Technology and the } \\
\text { Chains of Trust: Capital Markets and } \\
\text { Privatization in Russia and the Czech } \\
\text { Republic }\end{array}$ & Bruce Kogut and Andrew Spicer & August 2000 \\
\hline $\begin{array}{l}\text { No. } 334 \text { The Evolution of Market Integration } \\
\text { in Russia }\end{array}$ & Daniel Berkowitz and David N. DeJong & August 2000 \\
\hline $\begin{array}{l}\text { No. } 333 \text { Efficiency and Market Share in } \\
\text { Hungarian Corporate Sector }\end{array}$ & László Halpern and Gábor Körösi & July 2000 \\
\hline $\begin{array}{l}\text { No. } 332 \text { Search-Money-and-Barter Models of } \\
\text { Financial Stabilization }\end{array}$ & S.I. Boyarchenko and S.Z. Levendorskii & July 2000 \\
\hline $\begin{array}{l}\text { No. } 331 \text { Worker Training in a Restructuring } \\
\text { Economy: Evidence from the Russian } \\
\text { Transition }\end{array}$ & $\begin{array}{l}\text { Mark C. Berger, John S. Earle and Klara } \\
\text { Z. Sabirianova }\end{array}$ & August 2000 \\
\hline $\begin{array}{l}\text { No. } 330 \text { Economic Development in Palanpur } \\
\text { 1957-1993: A Sort of Growth }\end{array}$ & Peter Lanjouw & August 2000 \\
\hline $\begin{array}{l}\text { No. } 329 \text { Trust, Organizational Controls, } \\
\text { Knowledge Acquisition from the Foreign } \\
\text { Parents, and Performance in Vietnamese } \\
\text { International Joint Ventures }\end{array}$ & $\begin{array}{l}\text { Marjorie A. Lyles, Le Dang Doanh, and } \\
\text { Jeffrey Q. Barden }\end{array}$ & June 2000 \\
\hline
\end{tabular}

Working Papers are available at:

www.wdi.bus.umich.edu 


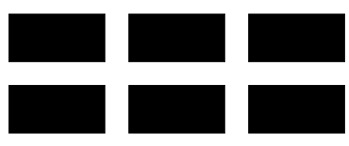

THE WILLIAM DAVIDSON INSTITUTE AT THE UNIVERSITY OF MICHIGAN BUSINESSSCHOOL

\begin{tabular}{|c|c|c|}
\hline $\begin{array}{l}\text { No. } 328 \text { Comparative Advertising in the } \\
\text { Global Marketplace: The Effects of Cultural } \\
\text { Orientation on Communication }\end{array}$ & $\begin{array}{l}\text { Zeynep Gürhan-Canli and Durairaj } \\
\text { Maheswaran }\end{array}$ & August 2000 \\
\hline $\begin{array}{l}\text { No. } 327 \text { Post Privatization Enterprise } \\
\text { Restructuring }\end{array}$ & Morris Bornstein & July 2000 \\
\hline No. 326 Who is Afraid of Political Instability? & Nauro F. Campos and Jeffrey B. Nugent & July 2000 \\
\hline $\begin{array}{l}\text { No. } 325 \text { Business Groups, the Financial } \\
\text { Market and Modernization }\end{array}$ & Raja Kali & June 2000 \\
\hline $\begin{array}{l}\text { No. } 324 \text { Restructuring with What Success? A } \\
\text { Case Study of Russian Firms }\end{array}$ & Susan Linz & July 2000 \\
\hline $\begin{array}{l}\text { No. } 323 \text { Priorities and Sequencing in } \\
\text { Privatization: Theory and Evidence from the } \\
\text { Czech Republic }\end{array}$ & $\begin{array}{l}\text { Nandini Gupta, John C. Ham and Jan } \\
\text { Svejnar }\end{array}$ & May 2000 \\
\hline $\begin{array}{l}\text { No. } 322 \text { Liquidity, Volatility, and Equity } \\
\text { Trading Costs Across Countries and Over } \\
\text { Time }\end{array}$ & $\begin{array}{l}\text { Ian Domowitz, Jack Glen and Ananth } \\
\text { Madhavan }\end{array}$ & March 2000 \\
\hline $\begin{array}{l}\text { No. } 321 \text { Equilibrium Wage Arrears: } \\
\text { Institutional Lock-In of Contractual Failure in } \\
\text { Russia }\end{array}$ & John S. Earle and Klara Z. Sabirianova & October 2000 \\
\hline $\begin{array}{l}\text { No. } 320 \text { Rethinking Marketing Programs for } \\
\text { Emerging Markets }\end{array}$ & Niraj Dawar and Amitava Chattopadhyay & June 2000 \\
\hline $\begin{array}{l}\text { No. } 319 \text { Public Finance and Low Equilibria in } \\
\text { Transition Economies; the Role of Institutions }\end{array}$ & Daniel Daianu and Radu Vranceanu & June 2000 \\
\hline $\begin{array}{l}\text { No. } 318 \text { Some Econometric Evidence on the } \\
\text { Effectiveness of Active Labour Market } \\
\text { Programmes in East Germany }\end{array}$ & Martin Eichler and Michael Lechner & June 2000 \\
\hline $\begin{array}{l}\text { No. } 317 \text { A Model of Russia's "Virtual } \\
\text { Economy" }\end{array}$ & R.E Ericson and B.W Ickes & May 2000 \\
\hline $\begin{array}{l}\text { No. } 316 \text { Financial Institutions, Financial } \\
\text { Contagion, and Financial Crises }\end{array}$ & Haizhou Huang and Chenggang Xu & March 2000 \\
\hline $\begin{array}{l}\text { No. } 315 \text { Privatization versus Regulation in } \\
\text { Developing Economies: The Case of West } \\
\text { African Banks }\end{array}$ & $\begin{array}{l}\text { Jean Paul Azam, Bruno Biais, and } \\
\text { Magueye Dia }\end{array}$ & February 2000 \\
\hline $\begin{array}{l}\text { No. } 314 \text { Is Life More Risky in the Open? } \\
\text { Household Risk-Coping and the Opening of } \\
\text { China's Labor Markets }\end{array}$ & John Giles & April 2000 \\
\hline $\begin{array}{l}\text { No. } 313 \text { Networks, Migration and Investment: } \\
\text { Insiders and Outsiders in Tirupur's Production } \\
\text { Cluster }\end{array}$ & Abhijit Banerjee and Kaivan Munshi & March 2000 \\
\hline $\begin{array}{l}\text { No. } 312 \text { Computational Analysis of the Impact } \\
\text { on India of the Uruguay Round and the } \\
\text { Forthcoming WTO Trade Negotiations }\end{array}$ & $\begin{array}{l}\text { Rajesh Chadha, Drusilla K. Brown, Alan } \\
\text { V. Deardorff and Robert M. Stern }\end{array}$ & March 2000 \\
\hline $\begin{array}{l}\text { No. } 311 \text { Subsidized Jobs for Unemployed } \\
\text { Workers in Slovakia }\end{array}$ & Jan. C. van Ours & May 2000 \\
\hline $\begin{array}{l}\text { No. } 310 \text { Determinants of Managerial Pay in } \\
\text { the Czech Republic }\end{array}$ & $\begin{array}{l}\text { Tor Eriksson, Jaromir Gottvald and Pavel } \\
\text { Mrazek }\end{array}$ & May 2000 \\
\hline $\begin{array}{l}\text { No. } 309 \text { The Great Human Capital } \\
\text { Reallocation: An Empirical Analysis of } \\
\text { Occupational Mobility in Transitional Russia }\end{array}$ & Klara Z. Sabirianova & October 2000 \\
\hline $\begin{array}{l}\text { No. } 308 \text { Economic Development, Legality, } \\
\text { and the Transplant Effect }\end{array}$ & $\begin{array}{l}\text { Daniel Berkowitz, Katharina Pistor, and } \\
\text { Jean-Francois Richard }\end{array}$ & February 2000 \\
\hline
\end{tabular}

Working Papers are available at: www.wdi.bus.umich.edu 


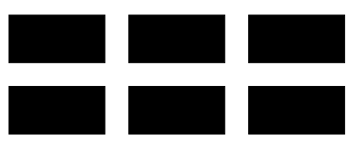

THE WILLIAM DAVIDSON INSTITUTE AT THE UNIVERSITY OF MICHIGAN BUSINESSSCHOOL

\begin{tabular}{|c|c|c|}
\hline $\begin{array}{l}\text { No. } 307 \text { Community Participation, Teacher } \\
\text { Effort, and Educational Outcome: The Case of } \\
\text { El Salvador's EDUCO Program }\end{array}$ & Yasuyuki Sawada & November 1999 \\
\hline $\begin{array}{l}\text { No. } 306 \text { Gender Wage Gap and Segregation in } \\
\text { Late Transition }\end{array}$ & Stepan Jurajda & May 2000 \\
\hline $\begin{array}{l}\text { No. } 305 \text { The Gender Pay Gap in the Transition } \\
\text { from Communism: Some Empirical Evidence }\end{array}$ & Andrew Newell and Barry Reilly & May 2000 \\
\hline $\begin{array}{l}\text { No. } 304 \text { Post-Unification Wage Growth in } \\
\text { East Germany }\end{array}$ & Jennifer Hunt & November 1998 \\
\hline $\begin{array}{l}\text { No. } 303 \text { How Does Privatization Affect } \\
\text { Workers? The Case of the Russian Mass } \\
\text { Privatization Program }\end{array}$ & Elizabeth Brainerd & May 2000 \\
\hline $\begin{array}{l}\text { No. } 302 \text { Liability for Past Environmental } \\
\text { Contamination and Privatization }\end{array}$ & Dietrich Earnhart & March 2000 \\
\hline No. 301 Varieties, Jobs and EU Enlargement & Tito Boeri and Joaquim Oliveira Martins & May 2000 \\
\hline No. 300 Employer Size Effects in Russia & Todd Idson & April 2000 \\
\hline $\begin{array}{l}\text { No. } 299 \text { Information Complements, } \\
\text { Substitutes, and Strategic Product Design }\end{array}$ & $\begin{array}{l}\text { Geoffrey G. Parker and Marshall W. Van } \\
\text { Alstyne }\end{array}$ & March 2000 \\
\hline $\begin{array}{l}\text { No. } 298 \text { Markets, Human Capital, and } \\
\text { Inequality: Evidence from Rural China }\end{array}$ & $\begin{array}{l}\text { Dwayne Benjamin, Loren Brandt, Paul } \\
\text { Glewwe, and Li Guo }\end{array}$ & May 2000 \\
\hline $\begin{array}{l}\text { No. } 297 \text { Corporate Governance in the Asian } \\
\text { Financial Crisis }\end{array}$ & $\begin{array}{l}\text { Simon Johnson, Peter Boone, Alasdair } \\
\text { Breach, and Eric Friedman }\end{array}$ & November 1999 \\
\hline $\begin{array}{l}\text { No. } 296 \text { Competition and Firm Performance: } \\
\text { Lessons from Russia }\end{array}$ & J. David Brown and John S. Earle & March 2000 \\
\hline $\begin{array}{l}\text { No. } 295 \text { Wage Determination in Russia: An } \\
\text { Econometric Investigation }\end{array}$ & Peter J. Luke and Mark E. Schaffer & March 2000 \\
\hline $\begin{array}{l}\text { No. 294: Can Banks Promote Enterprise } \\
\text { Restructuring?: Evidence From a Polish } \\
\text { Bank's Experience }\end{array}$ & John P. Bonin and Bozena Leven & March 2000 \\
\hline $\begin{array}{l}\text { No. 293: Why do Governments Sell Privatised } \\
\text { Companies Abroad? }\end{array}$ & $\begin{array}{l}\text { Bernardo Bortolotti, Marcella Fantini and } \\
\text { Carlo Scarpa }\end{array}$ & March 2000 \\
\hline $\begin{array}{l}\text { No. 292: Going Public in Poland: Case-by- } \\
\text { Case Privatizations, Mass Privatization and } \\
\text { Private Sector Initial Public Offerings }\end{array}$ & Wolfgang Aussenegg & December 1999 \\
\hline $\begin{array}{l}\text { No. 291: Institutional Technology and the } \\
\text { Chains of Trust: Capital Markets and } \\
\text { Privatization in Russia and the Czech } \\
\text { Republic }\end{array}$ & Bruce Kogut and Andrew Spicer & March 1999 \\
\hline $\begin{array}{l}\text { No. 290: Banking Crises and Bank Rescues: } \\
\text { The Effect of Reputation }\end{array}$ & Jenny Corbett and Janet Mitchell & January 2000 \\
\hline $\begin{array}{l}\text { No. 289: Do Active Labor Market Policies } \\
\text { Help Unemployed Workers to Find and Keep } \\
\text { Regular Jobs? }\end{array}$ & Jan C. van Ours & February 2000 \\
\hline $\begin{array}{l}\text { No. 288: Consumption Patterns of the New } \\
\text { Elite in Zimbabwe }\end{array}$ & Russell Belk & February 2000 \\
\hline $\begin{array}{l}\text { No. 287: Barter in Transition Economies: } \\
\text { Competing Explanations Confront Ukranian } \\
\text { Data }\end{array}$ & $\begin{array}{l}\text { Dalia Marin, Daniel Kaufmann and } \\
\text { Bogdan Gorochowskij }\end{array}$ & January 2000 \\
\hline $\begin{array}{l}\text { No. 286: The Quest for Pension Reform: } \\
\text { Poland's Security through Diversity }\end{array}$ & Marek Góra and Michael Rutkowski & January 2000 \\
\hline No. 285: Disorganization and Financial & Dalia Marin and Monika Schnitzer & October 1999 \\
\hline
\end{tabular}

Working Papers are available at: www.wdi.bus.umich.edu 


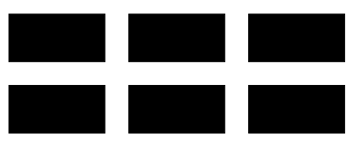

ThE WiLliam DAVIDSON InSTITUTE AT THE UNIVERSITY OF MICHIGAN BUSINESSSCHOOL

\begin{tabular}{|c|c|c|}
\hline Collapse & & \\
\hline $\begin{array}{l}\text { No. 284: Coordinating Changes in M-form } \\
\text { and U-form Organizations }\end{array}$ & $\begin{array}{l}\text { Yingyi Qian, Gérard Roland and } \\
\text { Chenggang Xu }\end{array}$ & May 1999 \\
\hline $\begin{array}{l}\text { No. 283: Why Russian Workers Do Not } \\
\text { Move: Attachment of Workers Through In- } \\
\text { Kind Payments }\end{array}$ & Guido Friebel and Sergei Guriev & October 1999 \\
\hline $\begin{array}{l}\text { No. 282: Lessons From Fiascos in Russian } \\
\text { Corporate Governance }\end{array}$ & Merritt B. Fox and Michael A. Heller & October 1999 \\
\hline $\begin{array}{l}\text { No. 281: Income Distribution and Price } \\
\text { Controls: Targeting a Social Safety Net } \\
\text { During Economic Transition }\end{array}$ & Michael Alexeev and James Leitzel & March 1999 \\
\hline $\begin{array}{l}\text { No. 280: Starting Positions, Reform Speed, } \\
\text { and Economic Outcomes in Transitioning } \\
\text { Economies }\end{array}$ & William Hallagan and Zhang Jun & January 2000 \\
\hline No. 279: The Value of Prominent Directors & Yoshiro Miwa \& J. Mark Ramseyer & October 1999 \\
\hline No. 278: The System Paradigm & János Kornai & April 1998 \\
\hline $\begin{array}{l}\text { No. 277: The Developmental Consequences of } \\
\text { Foreign Direct Investment in the Transition } \\
\text { from Socialism to Capitalism: The } \\
\text { Performance of Foreign Owned Firms in } \\
\text { Hungary }\end{array}$ & Lawrence Peter King & September 1999 \\
\hline $\begin{array}{l}\text { No. 276: Stability and Disorder: An } \\
\text { Evolutionary Analysis of Russia's Virtual } \\
\text { Economy }\end{array}$ & Clifford Gaddy and Barry W. Ickes & November 1999 \\
\hline $\begin{array}{l}\text { No. 275: Limiting Government Predation } \\
\text { Through Anonymous Banking: A Theory with } \\
\text { Evidence from China. }\end{array}$ & $\begin{array}{l}\text { Chong-En Bai, David D. Li, Yingyi Qian } \\
\text { and Yijiang Wang }\end{array}$ & July 1999 \\
\hline No. 274: Transition with Labour Supply & Tito Boeri & December 1999 \\
\hline $\begin{array}{l}\text { No. 273: Sectoral Restructuring and Labor } \\
\text { Mobility: A Comparative Look at the Czech } \\
\text { Republic }\end{array}$ & Vit Sorm and Katherine Terrell & November 1999 \\
\hline $\begin{array}{l}\text { No. 272: Published in: Journal of Comparative } \\
\text { Economics "Returns to Human Capital Under } \\
\text { the Communist Wage Grid and During the } \\
\text { Transition to a Market Economy" Vol. 27, pp. } \\
\text { 33-60 1999. }\end{array}$ & $\begin{array}{l}\text { Daniel Munich, Jan Svejnar and Katherine } \\
\text { Terrell }\end{array}$ & October 1999 \\
\hline $\begin{array}{l}\text { No. 271: Barter in Russia: Liquidity Shortage } \\
\text { Versus Lack of Restructuring }\end{array}$ & Sophie Brana and Mathilde Maurel & June 1999 \\
\hline $\begin{array}{l}\text { No. 270: Tests for Efficient Financial } \\
\text { Intermediation with Application to China }\end{array}$ & Albert Park and Kaja Sehrt & March 1999 \\
\hline $\begin{array}{l}\text { No. 269a: Russian Privatization and Corporate } \\
\text { Governance: What Went Wrong? }\end{array}$ & $\begin{array}{l}\text { Bernard Black, Reinier Kraakman and } \\
\text { Anna Tarassova }\end{array}$ & May 2000 \\
\hline $\begin{array}{l}\text { No. 269: Russian Privatization and Corporate } \\
\text { Governance: What Went Wrong? }\end{array}$ & $\begin{array}{l}\text { Bernard Black, Reinier Kraakman and } \\
\text { Anna Tarassova }\end{array}$ & September 1999 \\
\hline $\begin{array}{l}\text { No. 268: Are Russians Really Ready for } \\
\text { Capitalism? }\end{array}$ & Susan Linz & September 1999 \\
\hline $\begin{array}{l}\text { No. 267: Do Stock Markets Promote } \\
\text { Economic Growth? }\end{array}$ & $\begin{array}{l}\text { Randall K. Filer, Jan Hanousek and Nauro } \\
\text { Campos }\end{array}$ & September 1999 \\
\hline $\begin{array}{l}\text { No. 266: Objectivity, Proximity and } \\
\text { Adaptability in Corporate Governance }\end{array}$ & Arnoud W.A Boot and Jonathan R. Macey & September 1999 \\
\hline
\end{tabular}

Working Papers are available at: www.wdi.bus.umich.edu 


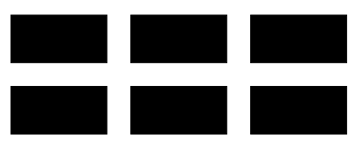

THE WILLIAM DAVIDSON INSTITUTE AT THE UNIVERSITY OF MICHIGAN BUSINESSSCHOOL

\begin{tabular}{|c|c|c|}
\hline $\begin{array}{l}\text { No. 265: When the Future is not What it Used } \\
\text { to Be: Lessons from the Western European } \\
\text { Experience to Forecasting Education and } \\
\text { Training in Transitional Economies }\end{array}$ & $\begin{array}{l}\text { Nauro F. Campos, Gerard Hughes, Stepan } \\
\text { Jurajda, and Daniel Munich }\end{array}$ & September 1999 \\
\hline $\begin{array}{l}\text { No. 264: The Institutional Foundation of } \\
\text { Foreign-Invested Enterprises (FIEs) in China }\end{array}$ & Yasheng Huang & September 1999 \\
\hline $\begin{array}{l}\text { No. 263: The Changing Corporate Governance } \\
\text { Paradigm: Implications for Transition and } \\
\text { Developing Countries }\end{array}$ & $\begin{array}{l}\text { Erik Berglof and Ernst-Ludwig von } \\
\text { Thadden }\end{array}$ & June 1999 \\
\hline No. 262: Law Enforcement and Transition & Gerard Roland and Thierry Verdier & May 1999 \\
\hline $\begin{array}{l}\text { No. 261: Soft Budget Constraints, Pecuniary } \\
\text { Externality, and the Dual Track System }\end{array}$ & Jiahua Che & June 2000 \\
\hline $\begin{array}{l}\text { No. 260: Missing Market in Labor Quality: } \\
\text { The Role of Quality Markets in Transition }\end{array}$ & Gary H. Jefferson & July 1999 \\
\hline $\begin{array}{l}\text { No. 259: Do Corporate Global Environmental } \\
\text { Standards in Emerging Markets Create or } \\
\text { Destroy Market Value }\end{array}$ & $\begin{array}{l}\text { Glen Dowell, Stuart Hart and Bernard } \\
\text { Yeung }\end{array}$ & June 1999 \\
\hline $\begin{array}{l}\text { No. 258: Public Training and Outflows from } \\
\text { Unemployment }\end{array}$ & Patrick A. Puhani & June 1999 \\
\hline $\begin{array}{l}\text { No. 257: Ownership Versus Environment: } \\
\text { Why are Public Sector Firms Inefficient? }\end{array}$ & Ann P. Bartel and Ann E. Harrison & June 1999 \\
\hline $\begin{array}{l}\text { No. 256: Taxation and Evasion in the Presence } \\
\text { of Exortion by Organized Crime }\end{array}$ & $\begin{array}{l}\text { Michael Alexeev, Eckhard Janeba and } \\
\text { Stefan Osborne }\end{array}$ & November 1999 \\
\hline $\begin{array}{l}\text { No. 255: Revisiting Hungary’s Bankruptcy } \\
\text { Episode }\end{array}$ & John P. Bonin and Mark E. Schaffer & September 1999 \\
\hline $\begin{array}{l}\text { No. 254: FDI in Emerging Markets: A Home- } \\
\text { Country View }\end{array}$ & Marina v.N Whitman & June 1999 \\
\hline $\begin{array}{l}\text { No. 253: The Asian Financial Crisis: What } \\
\text { Happened, and What is to be Done }\end{array}$ & Jeffrey D. Sachs and Wing Thye Woo & January 1999 \\
\hline $\begin{array}{l}\text { No. 252: Organizational Law as Asset } \\
\text { Partitioning }\end{array}$ & Henry Hansmann and Reinier Kraakman & September 1999 \\
\hline $\begin{array}{l}\text { No. 251: Consumer Behavior Research in } \\
\text { Emerging Consumer Markets: the Case of the } \\
\text { Optimum Stimulation Level in South Africa }\end{array}$ & $\begin{array}{l}\text { Jan-Benedict E. M. Steenkamp and Steven } \\
\text { M. Burgess }\end{array}$ & September 1999 \\
\hline $\begin{array}{l}\text { No. 250: Property Rights Formation and the } \\
\text { Organization of Exchange and Production in } \\
\text { Rural China }\end{array}$ & $\begin{array}{l}\text { Matthew A. Turner, Loren Brandt, and } \\
\text { Scott Rozelle }\end{array}$ & July 1998 \\
\hline $\begin{array}{l}\text { No. 249: Impacts of the Indonesian Economic } \\
\text { Crisis: Price Changes and the Poor }\end{array}$ & $\begin{array}{l}\text { James Levinsohn, Steven Berry, and Jed } \\
\text { Friedman }\end{array}$ & June 1999 \\
\hline $\begin{array}{l}\text { No. 248: Internal Barriers in the Transition of } \\
\text { Enterprises from Central Plan to Market }\end{array}$ & Charalambos Vlachoutsicos & July 1999 \\
\hline $\begin{array}{l}\text { No. 247: Spillovers from Multinationals in } \\
\text { Developing Countries: the Mechanisms at } \\
\text { Work }\end{array}$ & Richard E. Caves & June 1999 \\
\hline $\begin{array}{l}\text { No. 246: Dynamism and Inertia on the } \\
\text { Russian Labour Market: A Model of } \\
\text { Segmentation }\end{array}$ & $\begin{array}{l}\text { Irena Grosfeld, Claudia Senik-Leygonie, } \\
\text { Thierry Verdier, Stanislav Kolenikov and } \\
\text { Elena Paltseva }\end{array}$ & May 1999 \\
\hline $\begin{array}{l}\text { No. 245: Lessons from Bank Privatization in } \\
\text { Central Europe }\end{array}$ & John Bonin and Paul Wachtel & May 1999 \\
\hline $\begin{array}{l}\text { No. 244: Nominal-Real Tradeoffs and the } \\
\text { Effects of Monetary Policy: the Romanian } \\
\text { Experience }\end{array}$ & Christian Popa & December 1998 \\
\hline
\end{tabular}

Working Papers are available at: www.wdi.bus.umich.edu 


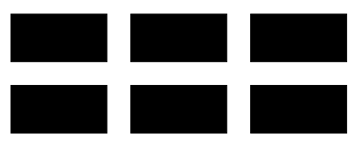

THE WILLIAM DAVIDSON INSTITUTE AT THE UNIVERSITY OF MICHIGAN BUSINESSSCHOOL

\begin{tabular}{|c|c|c|}
\hline $\begin{array}{l}\text { No. 243: Privatization, Political Risk and } \\
\text { Stock Market Development in Emerging } \\
\text { Economies }\end{array}$ & Enrico C. Perotti and Pieter van Oijen & March 1999 \\
\hline $\begin{array}{l}\text { No. 242: Investment Financing in Russian } \\
\text { Financial-Industrial Groups }\end{array}$ & Enrico C. Perotti and Stanislav Gelfer & October 1998 \\
\hline $\begin{array}{l}\text { No. 241: Can governments maintain hard } \\
\text { budget constraints? Bank lending and } \\
\text { financial isolation in Romania }\end{array}$ & $\begin{array}{l}\text { Octavian Carare, Constantijn Claessens, } \\
\text { Enrico C. Perotti }\end{array}$ & January 1999 \\
\hline $\begin{array}{l}\text { No. 240: Democratic Institutions and } \\
\text { Economic Reform: the Polish Case }\end{array}$ & $\begin{array}{l}\text { John E. Jackson, Jacek Klich, and } \\
\text { Krystyna Poznanska }\end{array}$ & April 1998 \\
\hline $\begin{array}{l}\text { No. 239: A Longitudinal Study of IJV } \\
\text { Performance in Eastern Europe }\end{array}$ & Keith D. Brouthers and Gary Bamossy & June 1999 \\
\hline $\begin{array}{l}\text { No. 238: Published in: Journal of Business } \\
\text { Venturing, "Firm Creation and Economic } \\
\text { Transitions" Vol. 14, Iss. 5,6 Sep/Nov 1999, } \\
\text { pp. 427-450. }\end{array}$ & $\begin{array}{l}\text { John E. Jackson, Jacek Klich, Krystyna } \\
\text { Poznanska }\end{array}$ & July 1998 \\
\hline $\begin{array}{l}\text { No. 237: Analysis of Entrepreneurial Attitudes } \\
\text { in Poland }\end{array}$ & $\begin{array}{l}\text { John E. Jackson and Aleksander S. } \\
\text { Marcinkowski }\end{array}$ & March 1997 \\
\hline $\begin{array}{l}\text { No. 236: Investment and Finance in De Novo } \\
\text { Private Firms: Empirical Results from the } \\
\text { Czech Republic, Hungary, and Poland }\end{array}$ & $\begin{array}{l}\text { Andrzej Bratkowski, Irena Grosfeld, Jacek } \\
\text { Rostowski }\end{array}$ & April 1999 \\
\hline $\begin{array}{l}\text { No. 235: Does a Soft Macroeconomic } \\
\text { Environment Induce Restructuring on the } \\
\text { Microeconomic Level during the Transition } \\
\text { Period? Evidence from Investment Behavior } \\
\text { of Czech Enterprises }\end{array}$ & Lubomír Lízal & June 1999 \\
\hline $\begin{array}{l}\text { No. 234: Banking Reform in China: Gradually } \\
\text { Strengthening Pillar or Fragile Reed? }\end{array}$ & John Bonin & June 1999 \\
\hline $\begin{array}{l}\text { No. 233: Theories of Soft Budget Constraints } \\
\text { and the Analysis of Banking Crises }\end{array}$ & Janet Mitchell & March 1999 \\
\hline $\begin{array}{l}\text { No. 232: Unemployment Risk, Precautionary } \\
\text { Savings, and Moonlighting in Russia }\end{array}$ & $\begin{array}{l}\text { Alessandra Guariglia and Byung-Yeon } \\
\text { Kim }\end{array}$ & June 1999 \\
\hline $\begin{array}{l}\text { No. 231: Investing in Turbulent Times: The } \\
\text { Investment Behavior of Polish Firms in the } \\
\text { Transition }\end{array}$ & $\begin{array}{l}\text { Josef C. Brada, Arthur E. King, and Chia- } \\
\text { Ying Ma }\end{array}$ & April 1999 \\
\hline $\begin{array}{l}\text { No. 230: The End of Moderate Inflation in } \\
\text { Three Transition Economies? }\end{array}$ & Josef C. Brada and Ali M. Kutan & April 1999 \\
\hline $\begin{array}{l}\text { No. 229: Back to the Future: The Growth } \\
\text { Prospects of Transition Economies } \\
\text { Reconsidered }\end{array}$ & Nauro F. Campos & April 1999 \\
\hline $\begin{array}{l}\text { No. 228: The Enterprise Isolation Program in } \\
\text { Russia }\end{array}$ & Simeon Djankov & April 1999 \\
\hline $\begin{array}{l}\text { No. 227: Published in: Journal of Comparative } \\
\text { Economics, "Ownership Concentration and } \\
\text { Corporate Performance in the Czech } \\
\text { Republic" 27(3), September 1999, pp. 498- } \\
\text { 513. }\end{array}$ & Stijn Claessens and Simeon Djankov & April 1999 \\
\hline $\begin{array}{l}\text { No. 226: Unemployment Benefit Entitlement } \\
\text { and Training Effects in Poland during } \\
\text { Transition }\end{array}$ & Patrick A. Puhani & March 1999 \\
\hline $\begin{array}{l}\text { No. 225: Transition at Whirlpool-Tatramat: } \\
\text { Case Studies }\end{array}$ & Hans Brechbuhl and Sonia Ferencikova & March 1999 \\
\hline
\end{tabular}

Working Papers are available at:

www.wdi.bus.umich.edu 


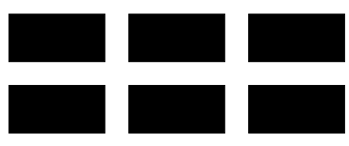

THE WILLIAM DAVIDSON INSTITUTE AT THE UNIVERSITY OF MICHIGAN BUSINESSSCHOOL

\begin{tabular}{|c|c|c|}
\hline $\begin{array}{l}\text { No. 224: Measuring Progress in Transition } \\
\text { and Towards EU Accession: A Comparison } \\
\text { of Manufacturing Firms in Poland, Romania, } \\
\text { and Spain }\end{array}$ & $\begin{array}{l}\text { Wendy Carlin, Saul Estrin, and Mark } \\
\text { Schaffer }\end{array}$ & March 1999 \\
\hline $\begin{array}{l}\text { No. 223: Product Market Competition in } \\
\text { Transition Economies: Increasing Varieties } \\
\text { and Consumer Loyalty }\end{array}$ & Mitsutoshi M. Adachi & March 1999 \\
\hline $\begin{array}{l}\text { No. 222: Opaque Markets and Rapid Growth: } \\
\text { the Superiority of Bank-Centered Financial } \\
\text { Systems for Developing Nations }\end{array}$ & Rodney Wallace & July 1999 \\
\hline $\begin{array}{l}\text { No. 221: Technology Spillovers through } \\
\text { Foreign Direct Investment }\end{array}$ & Yuko Kinoshita & January 1999 \\
\hline $\begin{array}{l}\text { No. 220: Managerial, Expertise and Team } \\
\text { Centered Forms of Organizing: A Cross- } \\
\text { Cultural Exploration of Independence in } \\
\text { Engineering Work }\end{array}$ & Leslie Perlow & January 1999 \\
\hline $\begin{array}{l}\text { No. 219: Household Structure and Labor } \\
\text { Demand in Agriculture: Testing for } \\
\text { Separability in Rural China }\end{array}$ & Audra J. Bowlus and Terry Sicular & January 1999 \\
\hline $\begin{array}{l}\text { No. 218: Competing Strategies of FDI and } \\
\text { Technology Transfer to China: American and } \\
\text { Japanese Firms }\end{array}$ & W. Mark Fruin and Penelope Prime & January 1999 \\
\hline $\begin{array}{l}\text { No. } 217 \text { Published in: Journal of Comparative } \\
\text { Economics, "Returns to Mobility in the } \\
\text { Transition to a Market Economy" Vol. 27, No. } \\
\text { 1, March 1999, pp. 4- }\end{array}$ & Tito Boeri and Christopher J. Flinn & January 1999 \\
\hline $\begin{array}{l}\text { No. } 216 \text { Published in: Journal of Comparative } \\
\text { Economics, "Labor Market Policies and } \\
\text { Unemployment in the Czech Republic." Vol. } \\
\text { 27, No. 1, March 1999, pp. 33-60. }\end{array}$ & Katherine Terrell and Vit Sorm & November 1998 \\
\hline $\begin{array}{l}\text { No. } 215 \text { Published in: Journal of Comparative } \\
\text { Economics, "Active Labor Market Policies in } \\
\text { Poland: Human Capital Enhancement, } \\
\text { Stigmatization or Benefit Churning?" Vol. 27, } \\
\text { No. 1, March 1999, pp. 61- }\end{array}$ & $\begin{array}{l}\text { Jochen Kluve, Hartmut Lehmann, and } \\
\text { Christoph M. Schmidt }\end{array}$ & December 1998 \\
\hline $\begin{array}{l}\text { No. } 214 \text { Published in: Journal of Comparative } \\
\text { Economics, "Does the Slovenian Public Work } \\
\text { Program Increase Participants' Chances to } \\
\text { Find a Job?" Vol. 27, No.1, March 1999, pp. } \\
\text { 113- }\end{array}$ & Milan Vodopivec & December 1998 \\
\hline $\begin{array}{l}\text { No. } 213 \text { Published in: Journal of Comparative } \\
\text { Economics, "Effects of Active Labor Market } \\
\text { Programs on the Transition Rate from } \\
\text { Unemployment into Regular Jobs in the } \\
\text { Slovak Republic." Vol. 27, No. 1, March } \\
\text { 1999, pp. 90- }\end{array}$ & Martina Lubyova and Jan C. van Ours & December 1998 \\
\hline $\begin{array}{l}\text { No. 212: The Marketing System in Bulgarian } \\
\text { Livestock Production - The Present State and } \\
\text { Evolutionary Processes During the Period of } \\
\text { Economic Transition }\end{array}$ & Yordan Staykov, Team Leader & October 1998 \\
\hline $\begin{array}{l}\text { No. 211: Bankruptcy Experience in Hungary } \\
\text { and the Czech Republic }\end{array}$ & Janet Mitchell & October 1998 \\
\hline
\end{tabular}

Working Papers are available at: www.wdi.bus.umich.edu 


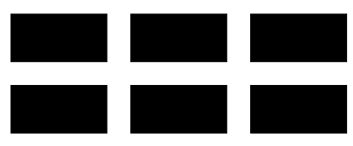

THE WILLIAM DAVIDSON INSTITUTE AT THE UNIVERSITY OF MICHIGAN BUSINESSSCHOOL

\begin{tabular}{|c|c|c|}
\hline $\begin{array}{l}\text { No 210: Values, Optimum Stimulation Levels } \\
\text { and Brand Loyalty: New Scales in New } \\
\text { Populations }\end{array}$ & Steven M. Burgess and Mari Harris & September 1998 \\
\hline $\begin{array}{l}\text { No. 209: Inherited Wealth, Corporate Control } \\
\text { and Economic Growth }\end{array}$ & $\begin{array}{l}\text { Randall K. Morck, David A. Stangeland, } \\
\text { and Bernard Yeung }\end{array}$ & September 1998 \\
\hline $\begin{array}{l}\text { No. 208: A Cultural Analysis of Homosocial } \\
\text { Reproduction and Contesting Claims to } \\
\text { Competence in Transitional Firms }\end{array}$ & Michael D. Kennedy & July 1998 \\
\hline $\begin{array}{l}\text { No. 207: From Survival to Success: The } \\
\text { Journey of Corporate Transformation at Haier. } \\
\text { Forthcoming in Teaching the Dinosaurs to } \\
\text { Dance: Organizational Change in Transition } \\
\text { Economies ed. Daniel Denison. }\end{array}$ & Arthur Yeung and Kenneth DeWoskin & July 1998 \\
\hline $\begin{array}{l}\text { No. 206: Why Do People Work If They Are } \\
\text { Not Paid? An Example from Eastern Europe. } \\
\text { Forthcoming in Teaching the Dinosaurs to } \\
\text { Dance: Organizational Change in Transition } \\
\text { Economies ed. Daniel Denison. }\end{array}$ & Irina L. Zinovieva & May 1998 \\
\hline $\begin{array}{l}\text { No. 205: Firm Ownership and Work } \\
\text { Motivation in Bulgaria and Hungary: An } \\
\text { Empirical Study of the Transition in the Mid- } \\
\text { 1990s. Forthcoming in Teaching the } \\
\text { Dinosaurs to Dance: Organizational Change in } \\
\text { Transition Economies ed. Daniel Denison. }\end{array}$ & $\begin{array}{l}\text { Robert A. Roe, Irina L. Zinovieva, } \\
\text { Elizabeth Dienes, and Laurens A. ten Horn }\end{array}$ & May 1998 \\
\hline $\begin{array}{l}\text { No. 204: Human Resource Management in the } \\
\text { Restructuring of Chinese Joint Ventures. } \\
\text { Forthcoming in Teaching the Dinosaurs to } \\
\text { Dance: Organizational Change in Transition } \\
\text { Economies ed. Daniel Denison. }\end{array}$ & Nandani Lynton & April 1998 \\
\hline $\begin{array}{l}\text { No. 203: Emergent Compensation Strategies } \\
\text { in Post-Socialist Poland: Understanding the } \\
\text { Cognitive Underpinnings of Management } \\
\text { Practices in a Transition Economy. } \\
\text { Forthcoming in Teaching the Dinosaurs to } \\
\text { Dance: Organizational Change in Transition } \\
\text { Economies ed. Daniel Denison. }\end{array}$ & Marc Weinstein & March 1998 \\
\hline $\begin{array}{l}\text { No. 202: Corporate Transformation and } \\
\text { Organizational Learning: The People's } \\
\text { Republic of China. Forthcoming in Teaching } \\
\text { the Dinosaurs to Dance: Organizational } \\
\text { Change in Transition Economies ed. Daniel } \\
\text { Denison. }\end{array}$ & Meinolf Dierkes and Zhang Xinhua & March 1998 \\
\hline $\begin{array}{l}\text { No. 201: Foreign Direct Investment as a } \\
\text { Factor of Change: The Case of Slovakia. } \\
\text { Forthcoming in Teaching the Dinosaurs to } \\
\text { Dance: Organizational Change in Transition } \\
\text { Economies ed. Daniel Denison. }\end{array}$ & Sonia Ferencikova & February 1998 \\
\hline $\begin{array}{l}\text { No. 200: Radical versus Incremental Change: } \\
\text { The Role of Capabilities, Competition, and } \\
\text { Leaders. Forthcoming in Teaching the } \\
\text { Dinosaurs to Dance: Organizational Change in } \\
\text { Transition Economies ed. Daniel Denison. }\end{array}$ & Karen L. Newman & February 1998 \\
\hline
\end{tabular}

Working Papers are available at: www.wdi.bus.umich.edu 


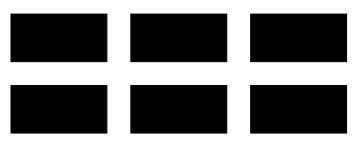

THE WILLIAM DAVIDSON INSTITUTE AT THE UNIVERSITY OF MICHIGAN BUSINESSSCHOOL

\begin{tabular}{|c|c|c|}
\hline $\begin{array}{l}\text { No. 199: The Emergence of Market Practices } \\
\text { in China's Economic Transition: Price Setting } \\
\text { Practices in Shanghai's Industrial Firms. } \\
\text { Forthcoming in Teaching the Dinosaurs to } \\
\text { Dance: Organizational Change in Transition } \\
\text { Economies ed. Daniel Denison. }\end{array}$ & Douglas Guthrie & February 1998 \\
\hline $\begin{array}{l}\text { No. 198: The Application of Change } \\
\text { Management Methods at Business } \\
\text { Organizations Operating in Hungary: } \\
\text { Challenges in the Business and Cultural } \\
\text { Environment and First Practical Experiences. } \\
\text { Forthcoming in Teaching the Dinosaurs to } \\
\text { Dance: Organizational Change in Transition } \\
\text { Economies ed. Daniel Denison. }\end{array}$ & Dr. János Fehér & January 1998 \\
\hline $\begin{array}{l}\text { No. 197: Organizational Changes in Russian } \\
\text { Industrial Enterprises: Mutation of Decision- } \\
\text { Making Structures and Transformations of } \\
\text { Ownership. Forthcoming in Teaching the } \\
\text { Dinosaurs to Dance: Organizational Change in } \\
\text { Transition Economies ed. Daniel Denison. }\end{array}$ & Igor B. Gurkov & January 1998 \\
\hline $\begin{array}{l}\text { No. 196: Understanding and Managing } \\
\text { Challenges to the Romanian Companies } \\
\text { during Transition. Forthcoming in Teaching } \\
\text { the Dinosaurs to Dance: Organizational } \\
\text { Change in Transition Economies ed. Daniel } \\
\text { Denison. }\end{array}$ & Dan Candea and Rodica M. Candea & January 1998 \\
\hline $\begin{array}{l}\text { No. 195: Insider Lending and Economic } \\
\text { Transition: The Structure, Function, and } \\
\text { Performance Impact of Finance Companies in } \\
\text { Chinese Business Groups. Forthcoming in } \\
\text { Teaching the Dinosaurs to Dance: } \\
\text { Organizational Change in Transition } \\
\text { Economies ed. Daniel Denison. }\end{array}$ & Lisa A. Keister & December 1997 \\
\hline $\begin{array}{l}\text { No. 194: Japanese Investment in Transitional } \\
\text { Economies: Characteristics and Performance. } \\
\text { Forthcoming in Teaching the Dinosaurs to } \\
\text { Dance: Organizational Change in Transition } \\
\text { Economies ed. Daniel Denison. }\end{array}$ & Paul W. Beamish and Andrew Delios & November 1997 \\
\hline $\begin{array}{l}\text { No. 193: Building Successful Companies in } \\
\text { Transition Economies. Forthcoming in } \\
\text { Teaching the Dinosaurs to Dance: } \\
\text { Organizational Change in Transition } \\
\text { Economies ed. Daniel Denison. }\end{array}$ & Dr. Ivan Perlaki & January 1998 \\
\hline $\begin{array}{l}\text { No. 192: Russian Communitariansim: An } \\
\text { Invisible Fist in the Transformation Process of } \\
\text { Russia. Forthcoming in Teaching the } \\
\text { Dinosaurs to Dance: Organizational Change in } \\
\text { Transition Economies ed. Daniel Denison. }\end{array}$ & Charalambos Vlachoutsicos & July 1998 \\
\hline No. 191: Teaching the Dinosaurs to Dance & Michal Cakrt & September 1997 \\
\hline $\begin{array}{l}\text { No. 190: Strategic Restructuring: Making } \\
\text { Capitalism in Post-Communist Eastern } \\
\text { Europe. Forthcoming in Teaching the }\end{array}$ & Lawrence P. King & September 1997 \\
\hline
\end{tabular}

Working Papers are available at: www.wdi.bus.umich.edu 


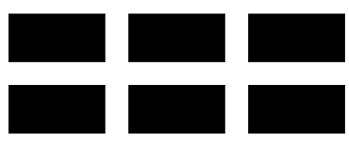

THE WILLIAM DAVIDSON INSTITUTE

AT THE UNIVERSITY OF MICHIGAN BUSINESSSCHOOL

\begin{tabular}{|c|c|c|}
\hline $\begin{array}{l}\text { Dinosaurs to Dance: Organizational Change in } \\
\text { Transition Economies ed. Daniel Denison. }\end{array}$ & & \\
\hline $\begin{array}{l}\text { No. 189: Published in: Regional Science and } \\
\text { Urban Economics, "Russia's Internal Border", } \\
29 \text { (5), September } 1999 .\end{array}$ & Daniel Berkowitz and David N. DeJong & July 1998 \\
\hline $\begin{array}{l}\text { No. 187: Corporate Structure and Performance } \\
\text { in Hungary }\end{array}$ & László Halpern and Gábor Kórsöi & July 1998 \\
\hline $\begin{array}{l}\text { No. 186: Performance of Czech Companies by } \\
\text { Ownership Structure }\end{array}$ & Andrew Weiss and Georgiy Nikitin & June 1998 \\
\hline $\begin{array}{l}\text { No. 185: Firm Performance in Bulgaria and } \\
\text { Estonia: The effects of competitive pressure, } \\
\text { financial pressure and disorganisation }\end{array}$ & Jozef Konings & July 1998 \\
\hline $\begin{array}{l}\text { No. 184: Investment and Wages during the } \\
\text { Transition: Evidence from Slovene Firms }\end{array}$ & Janez Prasnikar and Jan Svejnar & July 1998 \\
\hline $\begin{array}{l}\text { No. 183: Investment Portfolio under Soft } \\
\text { Budget: Implications for Growth, Volatility } \\
\text { and Savings }\end{array}$ & Chongen Bai and Yijiang Wang & July 1998 \\
\hline $\begin{array}{l}\text { No. 181: Delegation and Delay in Bank } \\
\text { Privatization }\end{array}$ & Loránd Ambrus-Lakatos and Ulrich Hege & July 1998 \\
\hline $\begin{array}{l}\text { No. 180: Financing Mechanisms and R\&D } \\
\text { Investment }\end{array}$ & Haizhou Huang and Chenggang Xu & July 1998 \\
\hline $\begin{array}{l}\text { No. 179: Organizational Culture and } \\
\text { Effectiveness: The Case of Foreign Firms in } \\
\text { Russia }\end{array}$ & Carl F. Fey and Daniel R. Denison & January 1999 \\
\hline $\begin{array}{l}\text { No. 178: Output and Unemployment } \\
\text { Dynamics in Transition }\end{array}$ & Vivek H. Dehejia and Douglas W. Dwyer & January 1998 \\
\hline $\begin{array}{l}\text { No. 177: Published in: Economics of } \\
\text { Transition,, "Bureaucracies in the Russian } \\
\text { Voucher Privatization" Vol. 8, No. 1, 2000, } \\
\text { pp. 37-57. }\end{array}$ & Guido Friebel & June 1998 \\
\hline $\begin{array}{l}\text { No. 176: Chronic Moderate Inflation in } \\
\text { Transition: The Tale of Hungary }\end{array}$ & János Vincze & June 1998 \\
\hline $\begin{array}{l}\text { No. 175: Privatisation and Market Structure in } \\
\text { a Transition Economy }\end{array}$ & John Bennett and James Maw & June 1998 \\
\hline $\begin{array}{l}\text { No. 174: Ownership and Managerial } \\
\text { Competition: Employee, Customer, or Outside } \\
\text { Ownership }\end{array}$ & Patrick Bolton and Chenggang $\mathrm{Xu}$ & June 1998 \\
\hline $\begin{array}{l}\text { No. 173: Intragovernment Procurement of } \\
\text { Local Public Good: A Theory of } \\
\text { Decentralization in Nondemocratic } \\
\text { Government }\end{array}$ & Chong-en Bai, Yu Pan and Yijiang Wang & June 1998 \\
\hline $\begin{array}{l}\text { No. 172: Political Instability and Growth in } \\
\text { Proprietary Economies }\end{array}$ & Jody Overland and Michael Spagat & August 1998 \\
\hline $\begin{array}{l}\text { No. 171: Published in Post-Communist } \\
\text { Economies, "Framework Issues in the } \\
\text { Privatization Strategies of the Czech Republic, } \\
\text { Hungary, and Poland" Vol. 11, no. 1 March } \\
\text { 1999. }\end{array}$ & Morris Bornstein & June 1998 \\
\hline $\begin{array}{l}\text { No. 170: Published in: European Journal of } \\
\text { Political Economy "Privatization, Ownership } \\
\text { Structure and Transparency: How to Measure } \\
\text { a Real Involvement of the State" 15(4), }\end{array}$ & Frantisek Turnovec & May 1998 \\
\hline
\end{tabular}

Working Papers are available at:

www.wdi.bus.umich.edu 


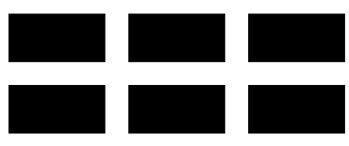

THE WILLIAM DAVIDSON INSTITUTE AT THE UNIVERSITY OF MICHIGAN BUSINESSSCHOOL

\begin{tabular}{|c|c|c|}
\hline November 1999, pp. 605-18. & & \\
\hline $\begin{array}{l}\text { No. } 169 \text { Published in: American Economic } \\
\text { Review, "Unemployment and the Social } \\
\text { Safety Net during Transitions to a Market } \\
\text { Economy: Evidence from Czech and Slovak } \\
\text { Men." Vol. 88, No. 5, Dec. 1998, pp. } 1117 \text { - } \\
1142 \text {. }\end{array}$ & $\begin{array}{l}\text { John C. Ham, Jan Svejnar, and Katherine } \\
\text { Terrell }\end{array}$ & December 1998 \\
\hline $\begin{array}{l}\text { No. 167: Voucher Privatization with } \\
\text { Investment Funds: An Institutional Analysis }\end{array}$ & David Ellerman & March 1998 \\
\hline $\begin{array}{l}\text { No. 166: Published in: Marketing Issues in } \\
\text { Transitional Economies, "Value Priorities and } \\
\text { Consumer Behavior in a Transitional } \\
\text { Economy: The Case of South Africa" ed. } \\
\text { Rajeev Batra. }\end{array}$ & $\begin{array}{l}\text { Steven M. Burgess and Jan-Benedict E.M. } \\
\text { Steenkamp }\end{array}$ & August 1998 \\
\hline $\begin{array}{l}\text { No. 164: Finance and Investment in } \\
\text { Transition: Czech Enterprises, 1993-1994 }\end{array}$ & Ronald Anderson and Chantal Kegels & September 1997 \\
\hline $\begin{array}{l}\text { No. 163: European Union Trade and } \\
\text { Investment Flows U-Shaping Industrial } \\
\text { Output in Central and Eastern Europe: Theory } \\
\text { and Evidence }\end{array}$ & Alexander Repkine and Patrick P. Walsh & April 1998 \\
\hline $\begin{array}{l}\text { No. 162: Skill Acquisition and Private Firm } \\
\text { Creation in Transition Economies }\end{array}$ & Zuzana Brixiova and Wenli Li & October 1999 \\
\hline No. 161: Corruption in Transition & Susanto Basu and David D. Li & May 1998 \\
\hline $\begin{array}{l}\text { No. 160a: Tenures that Shook the World: } \\
\text { Worker Turnover in Russia, Poland and } \\
\text { Britain }\end{array}$ & $\begin{array}{l}\text { Hartmut Lehmann and Jonathan } \\
\text { Wadsworth }\end{array}$ & November 1999 \\
\hline $\begin{array}{l}\text { No. 160: Tenures that Shook the World: } \\
\text { Worker Turnover in the Russian Federation } \\
\text { and Poland }\end{array}$ & $\begin{array}{l}\text { Hartmut Lehmann and Jonathan } \\
\text { Wadsworth }\end{array}$ & June 1998 \\
\hline $\begin{array}{l}\text { No. 159: Does Market Structure Matter? New } \\
\text { Evidence from Russia }\end{array}$ & Annette N. Brown and J. David Brown & June 1998 \\
\hline $\begin{array}{l}\text { No. 158: Structural Adjustment and Regional } \\
\text { Long Term Unemployment in Poland }\end{array}$ & Hartmut Lehmann and Patrick P. Walsh & June 1997 \\
\hline $\begin{array}{l}\text { No. 157: Baby Boom or Bust? Changing } \\
\text { Fertility in Post-Communist Czech Republic } \\
\text { and Slovakia }\end{array}$ & Robert S. Chase & April 1998 \\
\hline $\begin{array}{l}\text { No. } 156 \text { Published in: Leadership and } \\
\text { Organization Development Journal, "Leading } \\
\text { Radical Change in Transition Economies." } \\
\text { Vol. 19, No. 6, 1998, pp. 309-324. }\end{array}$ & Karen L. Newman & June 1998 \\
\hline $\begin{array}{l}\text { No. } 155 \text { Published in: Oxford Review of } \\
\text { Economic Policy, "From Theory into } \\
\text { Practice? Restructuring and Dynamism in } \\
\text { Transition Economies." Vol. 13, No. 2, } \\
\text { Summer 1997, pp. 77-105. }\end{array}$ & Wendy Carlin and Michael Landesmann & June 1997 \\
\hline $\begin{array}{l}\text { No. 154: The Model and the Reality: } \\
\text { Assessment of Vietnamese SOE Reform- } \\
\text { Implementation at the Firm Level }\end{array}$ & $\begin{array}{l}\text { Edmund Malesky, Vu Thanh Hung, Vu } \\
\text { Thi Dieu Anh, and Nancy K. Napier }\end{array}$ & July 1998 \\
\hline $\begin{array}{l}\text { No. } 153 \text { Published in: Journal of Comparative } \\
\text { Economics, "Causes of the Soft Budget } \\
\text { Constraint: Evidence on Three Explanations." } \\
\text { Vol. 26, No. 1, March 1998, pp. 104-116. }\end{array}$ & David D. Li and Minsong Liang & March 1998 \\
\hline
\end{tabular}

Working Papers are available at: www.wdi.bus.umich.edu 


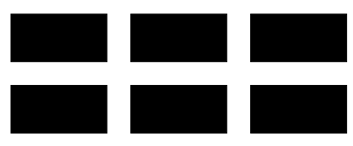

THE WILLIAM DAVIDSON INSTITUTE AT THE UNIVERSITY OF MICHIGAN BUSINESSSCHOOL

\begin{tabular}{|c|c|c|}
\hline $\begin{array}{l}\text { No. 152 Published in: Comparative Economic } \\
\text { Studies, "Enterprise Restructuring in Russia's } \\
\text { Transition Economy: Formal and Informal } \\
\text { Mechanisms." Vol. 40, No. 2, Summer 1998, } \\
\text { pp. 5-52. }\end{array}$ & Susan J. Linz and Gary Krueger & April 1998 \\
\hline $\begin{array}{l}\text { No. 151: Labor Productivity in Transition: A } \\
\text { Regional Analysis of Russian Industry }\end{array}$ & Susan J. Linz & May 1998 \\
\hline $\begin{array}{l}\text { No. 150: Tax Avoidance and the Allocation of } \\
\text { Credit. Forthcoming in Financial Systems in } \\
\text { Transition: The Design of Financial Systems } \\
\text { in Central Europe eds. Anna Meyendorff and } \\
\text { Anjan Thakor. }\end{array}$ & Anna Meyendorff & June 1998 \\
\hline $\begin{array}{l}\text { No. 149: Commitment, Versatility and } \\
\text { Balance: Determinants of Work Time } \\
\text { Standards and Norms in a Multi-Country } \\
\text { Study of Software Engineers }\end{array}$ & Leslie Perlow and Ron Fortgang & April 1998 \\
\hline $\begin{array}{l}\text { No. 148: Changes in Poland's Transfer } \\
\text { Payments in the 1990s: the Fate of Pensioners }\end{array}$ & Bozena Leven & June 1998 \\
\hline $\begin{array}{l}\text { No. 147: Environmental Protection and } \\
\text { Economic Development: The Case of the } \\
\text { Huaihe River Basin Cleanup Plan }\end{array}$ & $\begin{array}{l}\text { Robert Letovsky, Reze Ramazani, and } \\
\text { Debra Murphy }\end{array}$ & June 1998 \\
\hline $\begin{array}{l}\text { No. 146: Chief Executive Compensation } \\
\text { During Early Transition: Further Evidence } \\
\text { from Bulgaria }\end{array}$ & $\begin{array}{l}\text { Derek C. Jones, Takao Kato, and Jeffrey } \\
\text { Miller }\end{array}$ & June 1998 \\
\hline $\begin{array}{l}\text { No. } 145 \text { Published in: Economics of } \\
\text { Transition, "Women's Unemployment During } \\
\text { the Transition: Evidence from Czech and } \\
\text { Slovak Micro Data," Vol. 7, No. 1, May 1999, } \\
\text { pp. 47-78. }\end{array}$ & $\begin{array}{l}\text { John Ham, Jan Svejnar, and Katherine } \\
\text { Terrell }\end{array}$ & May 1998 \\
\hline No. 144: Investment and Wages in Slovenia & Janez Prasnikar & May 1998 \\
\hline $\begin{array}{l}\text { No. } 143 \text { Published in: Review of Financial } \\
\text { Studies, "Optimal Bankruptcy Laws Across } \\
\text { Different Economic Systems," 12(2), Summer } \\
\text { 1999, pgs. 347-77. }\end{array}$ & Elazar Berkovitch and Ronen Israel & March 1998 \\
\hline $\begin{array}{l}\text { No. 142: Industrial Policy and Poverty in } \\
\text { Transition Economies: Two Steps Forward or } \\
\text { One Step Back? }\end{array}$ & Susan J. Linz & March 1998 \\
\hline $\begin{array}{l}\text { No. 141: Collective Ownership and } \\
\text { Privatization of China's Village Enterprises }\end{array}$ & Suwen Pan and Albert Park & April 1998 \\
\hline $\begin{array}{l}\text { No. 140: A Comparative Look at Labor } \\
\text { Mobility in the Czech Republic: Where have } \\
\text { all the Workers Gone? }\end{array}$ & Vit Sorm and Katherine Terrell & April 1999 \\
\hline $\begin{array}{l}\text { No. 139: The Failure of the Government-Led } \\
\text { Program of Corporate Reorganization in } \\
\text { Romania }\end{array}$ & Simeon Djankov and Kosali Ilayperuma & September 1997 \\
\hline $\begin{array}{l}\text { No. 138: Ownership and Employment in } \\
\text { Russian Industry: 1992-1995 }\end{array}$ & Susan J. Linz & March 1998 \\
\hline $\begin{array}{l}\text { No. } 137 \text { Published in: Journal of Political } \\
\text { Economy, "Reform Without Losers: An } \\
\text { Interpretation of China's Dual-Track } \\
\text { Approach to Transition," Feb. 2000; Vol. 108, } \\
\text { Iss.1; pg. } 120\end{array}$ & $\begin{array}{l}\text { Lawrence J. Lau, Yingyi Qian, and Gerard } \\
\text { Roland }\end{array}$ & November 1997 \\
\hline
\end{tabular}

Working Papers are available at: www.wdi.bus.umich.edu 


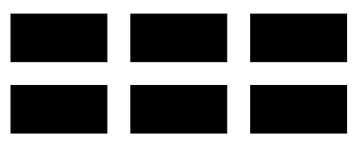

THE WILLIAM DAVIDSON INSTITUTE

AT THE UNIVERSITY OF MICHIGAN BUSINESSSCHOOL

\begin{tabular}{|c|c|c|}
\hline $\begin{array}{l}\text { No. } 136 \text { Published in: European Economic } \\
\text { Review, "The Political Economy of Mass } \\
\text { Privatization and the Risk of Expropriation," } \\
\text { 44(2), February 2000, pgs. } 393-421\end{array}$ & Klaus M. Schmidt & March 1998 \\
\hline $\begin{array}{l}\text { No. 135: Radical Organizational Change: The } \\
\text { Role of Starting Conditions, Competition, and } \\
\text { Leaders }\end{array}$ & Karen L. Newman & January 1998 \\
\hline $\begin{array}{l}\text { No. 134: To Restructure or Not to Restructure: } \\
\text { Informal Activities and Enterprise Behavior in } \\
\text { Transition }\end{array}$ & Clifford Gaddy and Barry W. Ickes & May 1998 \\
\hline $\begin{array}{l}\text { No. 133: Management 101: Behavior of Firms } \\
\text { in Transition Economies }\end{array}$ & Josef C. Brada & March 1998 \\
\hline $\begin{array}{l}\text { No. } 132 \text { Published in: Quarterly Journal of } \\
\text { Economics, "Interfirm Relationships and } \\
\text { Informal Credit in Vietnam," 114(4), Nov. } \\
\text { 1999, pgs. 1285-1320 }\end{array}$ & John McMillan and Christopher Woodruff & February 1998 \\
\hline $\begin{array}{l}\text { No. } 131 \text { Published in: Comparative Economic } \\
\text { Studies, "Will Restructuring Hungarian } \\
\text { Companies Innovate? An Investigation Based } \\
\text { on Joseph Berliner's Analysis of Innovation in } \\
\text { Soviet Industry." Vol. 40, No. 2, Summer } \\
\text { 1998, pp. 53-74. }\end{array}$ & John B. Bonin and Istvan Abel & March 1998 \\
\hline $\begin{array}{l}\text { No. 130: Published in The American } \\
\text { Economic Review, "Changing Incentives of } \\
\text { the Chinese Bureaucracy." May, } 1998 \text {. }\end{array}$ & David D. Li & January 1998 \\
\hline $\begin{array}{l}\text { No. 129: Restructuring Investment in } \\
\text { Transition: A Model of the Enterprise } \\
\text { Decision }\end{array}$ & Richard E. Ericson & January 1998 \\
\hline $\begin{array}{l}\text { No. } 128 \text { Published in: Comparative Economic } \\
\text { Studies, "Job Rights in Russian Firms: } \\
\text { Endangered or Extinct Institutions?" Vol. 40, } \\
\text { No. 4, Winter 1998, pp. 1-32. }\end{array}$ & Susan J. Linz & January 1998 \\
\hline $\begin{array}{l}\text { No. 127: Accounting for Growth in Post- } \\
\text { Soviet Russia }\end{array}$ & Daniel Berkowitz and David N. DeJong & January 1998 \\
\hline $\begin{array}{l}\text { No. } 126 \text { Published in: Economics of } \\
\text { Transition, "From Federalism, Chinese Style, } \\
\text { to Privatization Chinese Style," } 7(1), 1999, \\
\text { pgs. 103-31 }\end{array}$ & $\begin{array}{l}\text { Yuanzheng Cao, Yingyi Qian, and Barry } \\
\text { R. Weingast }\end{array}$ & December 1997 \\
\hline $\begin{array}{l}\text { No. 125: Market Discipline in Conglomerate } \\
\text { Banks: Is an Internal Allocation of Cost of } \\
\text { Capital Necessary as Incentive Device? } \\
\text { Forthcoming in Financial Systems in } \\
\text { Transition: The Design of Financial Systems } \\
\text { in Central Europe eds. Anna Meyendorff and } \\
\text { Anjan Thakor. }\end{array}$ & Arnoud W. A. Boot and Anjolein Schmeits & November 1997 \\
\hline $\begin{array}{l}\text { No. 124: Financial Discipline in the Enterprise } \\
\text { Sector in Transition Countries: How Does } \\
\text { China Compare? }\end{array}$ & Shumei Gao and Mark E. Schaffer & February 1998 \\
\hline $\begin{array}{l}\text { No. 123: Considerations of an Emerging } \\
\text { Marketplace: Managers' Perceptions in the } \\
\text { Southern African Economic Community }\end{array}$ & Brent Chrite and David Hudson & February 1998 \\
\hline No. 122: A Model of the Informal Economy in & Simon Commander and Andrei & November 1997 \\
\hline
\end{tabular}

Working Papers are available at: www.wdi.bus.umich.edu 


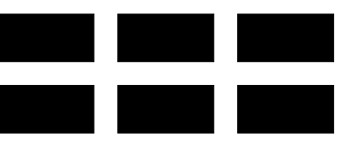

THE WILLIAM DAVIDSON INSTITUTE AT THE UNIVERSITY OF MICHIGAN BUSINESSSCHOOL

\begin{tabular}{|c|c|c|}
\hline Transition Economies & Tolstopiatenko & \\
\hline $\begin{array}{l}\text { No. 121: Local Labour Market Dynamics in } \\
\text { the Czech and Slovak Republics }\end{array}$ & Peter Huber and Andreas Worgotter & November 1997 \\
\hline $\begin{array}{l}\text { No. 119: Institutional Upheaval and Company } \\
\text { Transformation in Emerging Market } \\
\text { Economies }\end{array}$ & Karen L. Newman & March 1998 \\
\hline $\begin{array}{l}\text { No. 118: Industrial Decline and Labor } \\
\text { Reallocation in Romania }\end{array}$ & John S. Earle & October 1997 \\
\hline $\begin{array}{l}\text { No. 117: Notes for an Essay on the Soft } \\
\text { Budget Constraint }\end{array}$ & Lorand Ambrus-Lakatos & January 1997 \\
\hline $\begin{array}{l}\text { No. 116: Labor Demand During Transition in } \\
\text { Hungary }\end{array}$ & Gabor Korosi & October 1997 \\
\hline $\begin{array}{l}\text { No. 115: Enterprise Performance and } \\
\text { Managers' Profiles }\end{array}$ & Simeon Djankov and Stijn Claessens & December 1997 \\
\hline $\begin{array}{l}\text { No. 114b Employment and Wages in } \\
\text { Enterprises under Communism and in } \\
\text { Transition: Evidence From Central Europe and } \\
\text { Russia }\end{array}$ & Swati Basu, Saul Estrin, and Jan Svejnar & April 2000 \\
\hline $\begin{array}{l}\text { No. 114: Employment and Wage Behavior of } \\
\text { Enterprises in Transitional Economies }\end{array}$ & Swati Basu, Saul Estrin, and Jan Svejnar & October 1997 \\
\hline $\begin{array}{l}\text { No. 113: Preliminary Evidence on Active } \\
\text { Labor Programs' Impact in Hungary and } \\
\text { Poland }\end{array}$ & Christopher J. O'Leary & October 1997 \\
\hline $\begin{array}{l}\text { No. 111: Unemployment Benefits and } \\
\text { Incentives in Hungary: New Evidence }\end{array}$ & Joachim Wolff & October 1997 \\
\hline $\begin{array}{l}\text { No. 110: Published in: Empirical Economics, } \\
\text { "Long-Term Unemployment, Unemployment } \\
\text { Benefits and Social Assistance: The Polish } \\
\text { Experience" Empirical-Economics; 23(1-2), } \\
\text { 1998, pages 55-85. }\end{array}$ & Marek Gora and Christoph M. Schmidt & April 1997 \\
\hline $\begin{array}{l}\text { No. } 109 \text { Published in: Industrial and Labor } \\
\text { Relations Review, "Markets for Communist } \\
\text { Human Capital: Returns to Education and } \\
\text { Experience in Post-Communist Czech } \\
\text { Republic and Slovakia." Vol. 51, No. 3, April } \\
\text { 1998, pp. 401-423. }\end{array}$ & Robert S. Chase & October 1997 \\
\hline $\begin{array}{l}\text { No. 107: The Worker-Firm Matching in the } \\
\text { Transition: (Why) Are the Czechs More } \\
\text { Successful Than Others? }\end{array}$ & $\begin{array}{l}\text { Daniel Münich, Jan Svejnar, and Katherine } \\
\text { Terrell }\end{array}$ & October 1997 \\
\hline $\begin{array}{l}\text { No. } 106 \text { Published in: Journal of Comparative } \\
\text { Economics, "Job Creation, Job Destruction } \\
\text { and Growth of Newly Established, Privatized } \\
\text { and State-Owned Enterprises in Transition } \\
\text { Economies: Survey Evidence from Bulgaria, } \\
\text { Hungary, and Romania," Vol. 26, No.3, } \\
\text { September 1998, pp. 429-445. }\end{array}$ & Valentijn Bilsen and Jozef Konings & September 1998 \\
\hline $\begin{array}{l}\text { No. 105: Getting Behind the East-West } \\
\text { [German] Wage Differential: Theory and } \\
\text { Evidence }\end{array}$ & Michael Burda and Christoph Schmidt & May 1997 \\
\hline $\begin{array}{l}\text { No. 104: The Birth of the "Wage Curve" in } \\
\text { Hungary, 1989-95 }\end{array}$ & Gabor Kertesi and Janos Kollo & October 1997 \\
\hline No. 103: Published in: Journal of Comparative & Hartmut Lehmann, Jonathan Wadsworth, & October 1997 \\
\hline
\end{tabular}

Working Papers are available at:

www.wdi.bus.umich.edu 


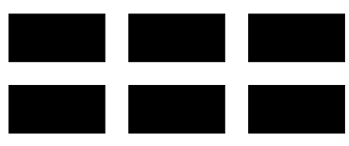

THE WILLIAM DAVIDSON INSTITUTE AT THE UNIVERSITY OF MICHIGAN BUSINESSSCHOOL

\begin{tabular}{|c|c|c|}
\hline $\begin{array}{l}\text { Economics, "Grime and Punishment: Job } \\
\text { Insecurity and Wage Arrears in the Russian } \\
\text { Federation" 27, 595-617 (1999). }\end{array}$ & and Alessandro Acquisti & \\
\hline No. 102: Social Networks in Transition & $\begin{array}{l}\text { Lorena Barberia, Simon Johnson, and } \\
\text { Daniel Kaufmann }\end{array}$ & October 1997 \\
\hline $\begin{array}{l}\text { No. 101: Depreciation and Russian Corporate } \\
\text { Finance: A Pragmatic Approach to Surviving } \\
\text { the Transition }\end{array}$ & Susan J. Linz & November 1997 \\
\hline No. 100: Romanian Financial System Reform & Anna Meyendorff and Anjan V. Thakor & November 1997 \\
\hline $\begin{array}{l}\text { No. 99: Proceedings of the Conference on } \\
\text { Strategic Alliances in Transitional Economies, } \\
\text { held May 20,1997 at the Davidson Institute }\end{array}$ & Edited by Cynthia Koch & May 1997 \\
\hline $\begin{array}{l}\text { No. 98: Institutions, Strain and the } \\
\text { Underground Economy }\end{array}$ & Daniel Daianu and Lucian Albu & November 1997 \\
\hline $\begin{array}{l}\text { No. 97: Structure and Strain in Explaining } \\
\text { Inter-Enterprise Arrears }\end{array}$ & Daniel Daianu & November 1997 \\
\hline $\begin{array}{l}\text { No. 96: Resource Misallocation and Strain: } \\
\text { Explaining Shocks in Post-Command } \\
\text { Economies }\end{array}$ & Daniel Daianu & November 1997 \\
\hline $\begin{array}{l}\text { No. 95: Published in: Finance-a-Uver, "Czech } \\
\text { Money Market: Emerging Links Among } \\
\text { Interest Rates." 48(2) } 1998 \text { pp. 99-109. }\end{array}$ & Jan Hanousek and Evzen Kocenda & November 1997 \\
\hline $\begin{array}{l}\text { No. 94: Pre-Reform Industry and the } \\
\text { State Monopsony in China }\end{array}$ & Xiao-Yuan Dong and Louis Putterman & October 1997 \\
\hline $\begin{array}{l}\text { No. 93: China's State-Owned Enterprises } \\
\text { In the First Reform Decade: } \\
\text { An Analysis of a Declining Monopsony }\end{array}$ & Xiao-Yuan Dong and Louis Putterman & October 1997 \\
\hline $\begin{array}{l}\text { No. 92: Expatriate Management in the Czech } \\
\text { Republic }\end{array}$ & Richard B. Peterson & September 1997 \\
\hline $\begin{array}{l}\text { No. 91: China and the Idea of Economic } \\
\text { Reform }\end{array}$ & Thomas G. Rawski & April 1997 \\
\hline $\begin{array}{l}\text { No. } 90 \text { Published in: China Economic Review, } \\
\text { "China's State Enterprise Reform: An } \\
\text { Overseas Perspective." Vol. 8, Spring 1997, } \\
\text { pp. 89-98. }\end{array}$ & Thomas G. Rawski & July 1997 \\
\hline $\begin{array}{l}\text { No. 89: The Economic Determinants of } \\
\text { Internal Migration Flows in Russia During } \\
\text { Transition }\end{array}$ & Annette N. Brown & July 1997 \\
\hline $\begin{array}{l}\text { No. 88: Gender Wage Gaps in China's Labor } \\
\text { Market: Size, Structure, Trends }\end{array}$ & $\begin{array}{l}\text { Margaret Maurer-Fazio, Thomas G. } \\
\text { Rawski, and Wei Zhang }\end{array}$ & July 1997 \\
\hline $\begin{array}{l}\text { No. 87: Privatisation in Central and Eastern } \\
\text { Europe }\end{array}$ & Saul Estrin & June 1997 \\
\hline $\begin{array}{l}\text { No. 86: Published in : Economics of } \\
\text { Transition, "The Effect of Privatization on } \\
\text { Wealth Distribution in Russia." v. 7, no. 2, } \\
\text { 1999, pp. 449-65 }\end{array}$ & Michael Alexeev & February 1998 \\
\hline $\begin{array}{l}\text { No. 85: Was Privatization in Eastern Germany } \\
\text { a Special Case? Some Lessons from the } \\
\text { Treuhand }\end{array}$ & Uwe Siegmund & September 1997 \\
\hline No. 84: Start-ups and Transition & Daniel M. Berkowitz and David J. Cooper & September 1997 \\
\hline $\begin{array}{l}\text { No. 83: Which Enterprises (Believe They) } \\
\text { Have Soft Budgets after Mass Privatization? }\end{array}$ & $\begin{array}{l}\text { James Anderson, Georges Korsun, and } \\
\text { Peter Murrell }\end{array}$ & October 1997 \\
\hline
\end{tabular}

Working Papers are available at: www.wdi.bus.umich.edu 


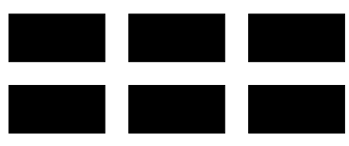

THE WILLIAM DAVIDSON INSTITUTE AT THE UNIVERSITY OF MICHIGAN BUSINESSSCHOOL

\begin{tabular}{|c|c|c|}
\hline Evidence from Mongolia & & \\
\hline $\begin{array}{l}\text { No. 82: Published in: European Economic } \\
\text { Review, "Unemployment Dynamics and the } \\
\text { Restructuring of the Slovak Unemployment } \\
\text { Benefit System." April, } 1997 .\end{array}$ & Martina Lubyova and Jan C. van Ours & June 1997 \\
\hline $\begin{array}{l}\text { No. 81: Determinants of Unemployment } \\
\text { Duration in Russia }\end{array}$ & Mark C. Foley & August 1997 \\
\hline $\begin{array}{l}\text { No. 80: The Many Faces of Information } \\
\text { Disclosure }\end{array}$ & Arnoud W.A. Boot and Anjan V. Thakor & October 1997 \\
\hline $\begin{array}{l}\text { No. 79: Published in: Journal of Finance, } \\
\text { "Foreign Speculators and Emerging Equity } \\
\text { Markets."v.22, iss. 2, 2000, pp. 565-613 }\end{array}$ & Geert Bekaert and Campbell R. Harvey & August 1997 \\
\hline $\begin{array}{l}\text { No. 78: The Relationship Between Economic } \\
\text { Factors and Equity Markets in Central Europe }\end{array}$ & Jan Hanousek and Randall K. Filer & June 1997 \\
\hline $\begin{array}{l}\text { No. } 77 \text { Published in: Economics of Transition, } \\
\text { "A Gini Decomposition Analysis of Inequality } \\
\text { in the Czech and Slovak Republics During the } \\
\text { Transition," Vol. 6, No.1, May 1998, pp. 23- } \\
\text { 46. }\end{array}$ & Thesia I. Garner and Katherine Terrell & May 1998 \\
\hline $\begin{array}{l}\text { No. 76: China's Emerging Market for Property } \\
\text { Rights: Theoretical and Empirical } \\
\text { Perspectives }\end{array}$ & Gary H. Jefferson and Thomas G. Rawski & June 1997 \\
\hline $\begin{array}{l}\text { No. 75b: Test of Permanent Income } \\
\text { Hypothesis on Czech Voucher Privatization }\end{array}$ & Jan Hanousek and Zdenek Tima & October 1997 \\
\hline $\begin{array}{l}\text { No. 74: Determinants of Performance of } \\
\text { Manufacturing Firms in Seven European } \\
\text { Transition Economies }\end{array}$ & $\begin{array}{l}\text { Stijn Claessens, Simeon Djankov, and } \\
\text { Gerhard Pohl }\end{array}$ & February 1997 \\
\hline $\begin{array}{l}\text { No. } 73 \text { Published in: Economics of Transition, } \\
\text { "The Restructuring of Large Firms in Slovak } \\
\text { Republic." Vol. 6, No. 1, May 1998, pp. 67- } \\
85\end{array}$ & Simeon Djankov and Gerhard Pohl & May 1998 \\
\hline $\begin{array}{l}\text { No. 72: Law, Relationships, and Private } \\
\text { Enforcement: Transactional Strategies of } \\
\text { Russian Enterprises }\end{array}$ & $\begin{array}{l}\text { Kathryn Hendley, Peter Murrell, and Randi } \\
\text { Ryterman }\end{array}$ & November 1998 \\
\hline $\begin{array}{l}\text { No. 71: Giving Credit Where Credit Is Due: } \\
\text { The Changing Role of Rural Financial } \\
\text { Institutions in China }\end{array}$ & Albert Park, Loren Brandt, and John Giles & March 1997 \\
\hline $\begin{array}{l}\text { No. 70: Privatization Versus Competition: } \\
\text { Changing Enterprise Behavior in Russia }\end{array}$ & John S. Earle and Saul Estrin & Spring 1997 \\
\hline $\begin{array}{l}\text { No. 69: Russian Managers under Storm: } \\
\text { Explicit Reality and Implicit Leadership } \\
\text { Theories (A Pilot Exploration) }\end{array}$ & Igor Gurkov & October 1998 \\
\hline $\begin{array}{l}\text { No. 68: The Political Economy of Central- } \\
\text { Local Relations in China: Inflation and } \\
\text { Investment Controls During the Reform Era }\end{array}$ & Yasheng Huang & Spring 1997 \\
\hline $\begin{array}{l}\text { No. 67: Between Two Coordination Failures: } \\
\text { Automotive Industrial Policy in China with a } \\
\text { Comparison to Korea }\end{array}$ & Yasheng Huang & Spring 1997 \\
\hline $\begin{array}{l}\text { No. } 66 \text { Published in: Post-Soviet Geography } \\
\text { and Economics, "Red Executives in Russia’s } \\
\text { Transition Economy." Vol. 27, No. 10, } \\
\text { November 1996, pp. 633-651. }\end{array}$ & Susan J. Linz & January 1997 \\
\hline
\end{tabular}

Working Papers are available at: www.wdi.bus.umich.edu 


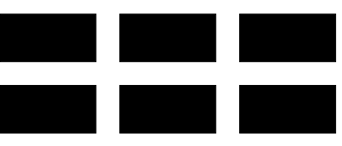

THE WILLIAM DAVIDSON INSTITUTE AT THE UNIVERSITY OF MICHIGAN BUSINESSSCHOOL

\begin{tabular}{|c|c|c|}
\hline $\begin{array}{l}\text { No. } 65 \text { Published in: Industrial and Corporate } \\
\text { Change, "On the Sequencing of Privatization } \\
\text { in Transition Economies." Vol. 7, No. 1, } \\
1998 .\end{array}$ & Gautam Ahuja and Sumit K. Majumdar & April 1997 \\
\hline $\begin{array}{l}\text { No. 64: Published in: Journal of Law and } \\
\text { Economics, "Foreign Ownership and } \\
\text { Profitability: Property Rights, Control and the } \\
\text { Performance of Firms in Indian Industry" } \\
\text { 42(1), April } 1999, \text { pp. 209-38. }\end{array}$ & $\begin{array}{l}\text { Pradeep K. Chhibber and Sumit K. } \\
\text { Majumdar }\end{array}$ & April 1997 \\
\hline $\begin{array}{l}\text { No. 63: How Taxing Is Corruption on } \\
\text { International Investors? }\end{array}$ & Shang-Jin Wei & February 1997 \\
\hline $\begin{array}{l}\text { No. 62: What Can We Learn from the } \\
\text { Experience of Transitional Economies with } \\
\text { Labour Market Policies? }\end{array}$ & Tito Boeri & 1997 \\
\hline $\begin{array}{l}\text { No. 61: Published in: Accounting } \\
\text { Organizations and Society, "Economic } \\
\text { Transition, Strategy and the Evolution of } \\
\text { Management Accounting Practices: The Case } \\
\text { of India" 24(5,6), Jul/Aug 1999, pp. 379-412. }\end{array}$ & $\begin{array}{l}\text { Shannon W. Anderson and William N. } \\
\text { Lanen }\end{array}$ & April 1997 \\
\hline $\begin{array}{l}\text { No. 60a: Enterprise Investment During the } \\
\text { Transition: Evidence from Czech Panel Data }\end{array}$ & Lubomír Lizal and Jan Svejnar & December 1997 \\
\hline $\begin{array}{l}\text { No. 59: Published in: Journal of Law, } \\
\text { Economics, and Organization, "Institutional } \\
\text { Environment, Community Government, and } \\
\text { Corporate Governance: Understanding } \\
\text { China's Township-Village Enterprises." 14(1), } \\
\text { April 1998, pages 1-23 }\end{array}$ & Jiahua Che and Yingyi Qian & April 1997 \\
\hline $\begin{array}{l}\text { No. 58: From the Grabbing Hand to the } \\
\text { Helping Hand }\end{array}$ & Jiahua Che & June 2000 \\
\hline $\begin{array}{l}\text { No. 57: Published in: Brookings Papers on } \\
\text { Economic Activity, "The Unofficial Economy } \\
\text { in Transition." 1: 1998. }\end{array}$ & $\begin{array}{l}\text { Simon Johnson, Daniel Kaufmann, and } \\
\text { Andrei Schleifer }\end{array}$ & June 1997 \\
\hline $\begin{array}{l}\text { No. 56: Taxes and Government Incentives: } \\
\text { Eastern Europe vs. China }\end{array}$ & Roger H. Gordon and David D. Li & April 1997 \\
\hline No. 55: Corruption and Reform & Susanto Basu and David Li & June 1996 \\
\hline $\begin{array}{l}\text { No. 54: Decentralization and the } \\
\text { Macroeconomic Consequences of } \\
\text { Commitment to State-Owned Firms }\end{array}$ & Loren Brandt and Xiaodong Zhu & June 1997 \\
\hline $\begin{array}{l}\text { No. 53: Published in: The International } \\
\text { Journal of Industrial Organization, } \\
\text { "Competitive Shocks and Industrial Structure: } \\
\text { The Case of Polish Manufacturing." August, } \\
\text { 1999. . }\end{array}$ & Pankaj Ghemawat and Robert E. Kennedy & May 1997 \\
\hline $\begin{array}{l}\text { No. 52: Published in: The Quarterly Journal of } \\
\text { Economics, "Insecure Property Rights and } \\
\text { Government Ownership of Firms." May, } \\
1998 .\end{array}$ & Jiahua Che and Yingyi Qian & May 1997 \\
\hline $\begin{array}{l}\text { No. 51: Incentives, Scale Economies, and } \\
\text { Organizational Form }\end{array}$ & $\begin{array}{l}\text { Eric Maskin, Yingyi Qian, and Chenggang } \\
\mathrm{Xu}\end{array}$ & May 1997 \\
\hline $\begin{array}{l}\text { No. 50: Published in: Post-Soviet-Affairs, } \\
\text { "End of the Tunnel? The Effects of Financial } \\
\text { Stabilization in Russia" April-June 1997, }\end{array}$ & $\begin{array}{l}\text { Barry W. Ickes, Peter Murrell, and Randi } \\
\text { Ryterman }\end{array}$ & March 1997 \\
\hline
\end{tabular}

Working Papers are available at: www.wdi.bus.umich.edu 


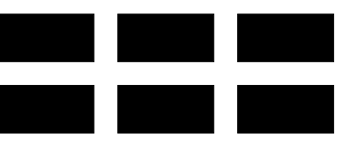

THE WILLIAM DAVIDSON INSTITUTE AT THE UNIVERSITY OF MICHIGAN BUSINESSSCHOOL

\begin{tabular}{|c|c|c|}
\hline pages $105-33$ & & \\
\hline $\begin{array}{l}\text { No. 49: The Evolution of Bank Credit Quality } \\
\text { in Transition: Theory and Evidence from } \\
\text { Romania }\end{array}$ & Enrico C. Perotti and Octavian Carare & October 1996 \\
\hline $\begin{array}{l}\text { No. 48: Where Do the Leaders Trade? } \\
\text { Information Revelation and Interactions } \\
\text { Between the Segments of Czech Capital } \\
\text { Markets }\end{array}$ & Jan Hanousek and Libor Nemecek & May 1997 \\
\hline $\begin{array}{l}\text { No. 47: Firms' Heterogeneity in Transition: } \\
\text { Evidence from a Polish Panel Data Set }\end{array}$ & Irena Grosfeld and Jean-François Nivet & May 1997 \\
\hline $\begin{array}{l}\text { No. 46: Strategic Creditor Passivity, } \\
\text { Regulation, and Bank Bailouts }\end{array}$ & Janet Mitchell & May 1997 \\
\hline $\begin{array}{l}\text { No. 45a: Published in: Journal of Public } \\
\text { Economics, "Tax Rights in Transition } \\
\text { Economies: A Tragedy of the Commons." 76, } \\
\text { 2000, pp. 369-397 }\end{array}$ & Daniel M. Berkowitz and Wei Li & September 1997 \\
\hline $\begin{array}{l}\text { No. 44a: The Information Content of Stock } \\
\text { Markets: Why do Emerging Markets have } \\
\text { Synchronous Stock Price Movements? } \\
\text { (forthcoming in the Journal of Financial } \\
\text { Economics). }\end{array}$ & $\begin{array}{l}\text { Randall Morck, Bernard Yeung, and } \\
\text { Wayne Yu }\end{array}$ & February 1999 \\
\hline $\begin{array}{l}\text { No. 43: Agency in Project Screening and } \\
\text { Termination Decisions: Why Is Good Money } \\
\text { Thrown After Bad? }\end{array}$ & Chong-en Bai and Yijiang Wang & May 1997 \\
\hline $\begin{array}{l}\text { No. 42: Published in: Economics of } \\
\text { Transition, "Channels of Redistribution: } \\
\text { Inequality and Poverty in the Russian } \\
\text { Transition." Vol. } 7 \text { (2) } 1999 .\end{array}$ & $\begin{array}{l}\text { Simon Commander, Andrei } \\
\text { Tolstopiatenko, and Ruslan Yemtsov }\end{array}$ & May 1997 \\
\hline $\begin{array}{l}\text { No. 41: Published in: Economics of } \\
\text { Transition, "Labour Market Characteristics } \\
\text { and Profitability: Econometric Analysis of } \\
\text { Hungarian Exporting Firms, 1986-1995" 6(1), } \\
\text { May 1998, pages 145-62 }\end{array}$ & László Halpern and Gabor Korosi & May 1997 \\
\hline $\begin{array}{l}\text { No. 40: Published in: the Harvard Law } \\
\text { Review, "The Tragedy of the Anticommons: } \\
\text { Property in the Transition from Marx to } \\
\text { Markets." January } 1998 \text {. }\end{array}$ & Michael Heller & February 1997 \\
\hline $\begin{array}{l}\text { No. 39: Privatization and Managerial } \\
\text { Efficiency }\end{array}$ & Olivier Debande and Guido Friebel & May 1997 \\
\hline $\begin{array}{l}\text { No. } 38 \text { Published in: The Quarterly Journal of } \\
\text { Economics, "Disorganization." Vol. 112, No. } \\
\text { 4, November 1997, pp. 1091-1126. }\end{array}$ & Olivier Blanchard and Michael Kremer & January 1997 \\
\hline $\begin{array}{l}\text { No. 37: Published in: Economics of } \\
\text { Transition, "Transition and the Output Fall." } \\
\text { 7(1), 1999, pages 1-28. }\end{array}$ & Gérard Roland and Thierry Verdier & March 1997 \\
\hline $\begin{array}{l}\text { No. 36: Restructuring an Industry During } \\
\text { Transition: A Two-Period Model }\end{array}$ & Richard Ericson & September 1996 \\
\hline $\begin{array}{l}\text { No. 34: The East-West Joint Venture: BC } \\
\text { Torsion Case Study }\end{array}$ & Sonia Ferencikova and Vern Terpstra & December 1998 \\
\hline $\begin{array}{l}\text { No. } 33 \text { Published in: Journal of Comparative } \\
\text { Economics, "Quantifying Price Liberalization } \\
\text { in Russia." Vol. 26, No. 4, December 1998, }\end{array}$ & $\begin{array}{l}\text { Daniel Berkowitz, David DeJong, and } \\
\text { Steven Husted }\end{array}$ & December 1998 \\
\hline
\end{tabular}

Working Papers are available at: www.wdi.bus.umich.edu 


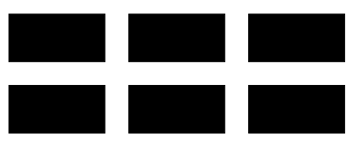

THE WILLIAM DAVIDSON INSTITUTE AT THE UNIVERSITY OF MICHIGAN BUSINESSSCHOOL

\begin{tabular}{|c|c|c|}
\hline pp. 735-737. & & \\
\hline $\begin{array}{l}\text { No. 32: What Can North Korea Learn from } \\
\text { China's Market Reforms? }\end{array}$ & John McMillan & September 1996 \\
\hline $\begin{array}{l}\text { No. 31: Published in : China-Economic- } \\
\text { Review, "Towards a Model of China as a } \\
\text { Partially Reformed Developing Economy } \\
\text { Under a Semifederalist Government.", 9(1), } \\
\text { Spring 1998, pages 1-23. }\end{array}$ & Yijiang Wang and Chun Chang & March 1997 \\
\hline $\begin{array}{l}\text { No. 30: Convergence in Output in Transition } \\
\text { Economies: Central and Eastern Europe, } \\
\text { 1970-1995 }\end{array}$ & Saul Estrin and Giovanni Urga & February 1997 \\
\hline $\begin{array}{l}\text { No. 29: Published in: Economics of } \\
\text { Transition, "Altered Band and Exchange } \\
\text { Volatility." Volume 6, no. 1, 1998, 173-181. }\end{array}$ & Evzen Kocenda & March 1997 \\
\hline $\begin{array}{l}\text { No. 28: Published in: Quarterly Journal of } \\
\text { Economics, "Public Versus Private Ownership } \\
\text { of Firms: Evidence from Rural China." } \\
\text { Volume 113, no. 3, August 1998, 773-808. }\end{array}$ & Hehui Jin and Yingyi Qian & January 1997 \\
\hline $\begin{array}{l}\text { No. 27: East-West Joint Ventures in a } \\
\text { Transitional Economy: The Case of Slovakia }\end{array}$ & Sonia Ferencikova & March 1997 \\
\hline $\begin{array}{l}\text { No. 26: Published in Economic Analysis } \\
\text { "Behavior of a Slovenian Firm in Transition" } \\
\text { Vol. 1, no. 1, 1998, 57-73. }\end{array}$ & Janez Prasnikar & February 1997 \\
\hline $\begin{array}{l}\text { No. 25: Cultural Encounters and Claims to } \\
\text { Expertise in Postcommunist Capitalism }\end{array}$ & Michael D. Kennedy & February 1997 \\
\hline $\begin{array}{l}\text { No. 24: ZVU a.s.: Investment Funds on the } \\
\text { Board of Directors of an Engineering Giant }\end{array}$ & Tory Wolff & August 1995 \\
\hline $\begin{array}{l}\text { No. 23: The Role of Investment Funds in the } \\
\text { Czech Republic (joint publication with Czech } \\
\text { Management Center) }\end{array}$ & Dusan Triska & June 1996 \\
\hline $\begin{array}{l}\text { No. 22: Czech Investment Fund Industry: } \\
\text { Development and Behaviour (joint publication } \\
\text { with Czech Management Center) }\end{array}$ & Richard Podpiera & May 1996 \\
\hline $\begin{array}{l}\text { No. 21: Restructuring of Czech Firms: An } \\
\text { Example of Gama, a.s. (joint publication with } \\
\text { Czech Management Center) }\end{array}$ & Antonin Bulin & June 1996 \\
\hline $\begin{array}{l}\text { No. 20: YSE Funds: A Story of Czech } \\
\text { Investment Funds (joint publication with } \\
\text { Czech Management Center) }\end{array}$ & Michal Otradovec & November 1995 \\
\hline $\begin{array}{l}\text { No. 19: První Investicni a.s., The First } \\
\text { Investment Corporation (joint publication } \\
\text { with Czech Management Center) }\end{array}$ & Jaroslav Jirasek & August 1995 \\
\hline $\begin{array}{l}\text { No. 18: PPF a.s., The First Private Investment } \\
\text { Fund (joint publication with Czech } \\
\text { Management Center) }\end{array}$ & Michal Otradovec & November 1995 \\
\hline $\begin{array}{l}\text { No. } 17 \text { Published in: Post-Soviet Geography } \\
\text { and Economics, "Russia's Managers in } \\
\text { Transition: Pilferers or Paladins?" Vol. 37, } \\
\text { o.7 (September 1996), pp. 397-426. }\end{array}$ & Susan J. Linz and Gary Krueger & November 1996 \\
\hline $\begin{array}{l}\text { No. 16: Banks in Transition-Investment } \\
\text { Opportunities in Central Europe and Russia } \\
\text { Edited Transcript from } 31 \text { May } 1996\end{array}$ & $\begin{array}{l}\text { With commentary and edited by Anna } \\
\text { Meyendorff }\end{array}$ & January 1997 \\
\hline
\end{tabular}

Working Papers are available at: www.wdi.bus.umich.edu 


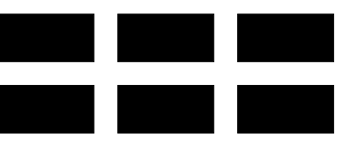

THE WILLIAM DAVIDSON INSTITUTE AT THE UNIVERSITY OF MICHIGAN BUSINESSSCHOOL

\begin{tabular}{|c|c|c|}
\hline Conference in New York City & & \\
\hline $\begin{array}{l}\text { No. 15: Marketing in Transitional Economies: } \\
\text { Edited Transcript \& Papers from } 1 \text { April } 1996 \\
\text { Conference in Ann Arbor, Michigan }\end{array}$ & Compiled by The Davidson Institute & December 1996 \\
\hline $\begin{array}{l}\text { No. 14: Pensions in the Former Soviet Bloc: } \\
\text { Problems and Solutions. Published by } \\
\text { Council on Foreign Relations. "The Coming } \\
\text { Global Pension Crisis" New York, } 1997\end{array}$ & Jan Svejnar & November 1996 \\
\hline $\begin{array}{l}\text { No. 13: Enterprise Restructuring and } \\
\text { Performance in the Transition. Forthcoming } \\
\text { in Financial Systems in Transition: The } \\
\text { Design of Financial Systems in Central } \\
\text { Europe eds. Anna Meyendorff and Anjan } \\
\text { Thakor. }\end{array}$ & $\begin{array}{l}\text { Lubomir Lizal, Miroslav Singer, and Jan } \\
\text { Svejnar }\end{array}$ & December 1996 \\
\hline $\begin{array}{l}\text { No. } 12 \text { Published in: Journal of International } \\
\text { Marketing, "Executive Insights: Marketing } \\
\text { Issues and Challenges in Transitional } \\
\text { Economies." Vol. 5, No. 4, 1997, pp. 95-114. } \\
\text { Also published in: Marketing Issues in } \\
\text { Transitional Economies ed. Rajeev Batra. }\end{array}$ & Rajeev Batra & April 1997 \\
\hline $\begin{array}{l}\text { No. 11: Worker Trust and System } \\
\text { Vulnerability in the Transition from Socialism } \\
\text { to Capitalism }\end{array}$ & Andrew Schotter & August 1996 \\
\hline $\begin{array}{l}\text { No. } 10 \text { Published in: Comparative Economic } \\
\text { Studies, "Russian Firms in Transition: } \\
\text { Champions, Challengers, and Chaff." Vol. 39, } \\
\text { No.2, Summer 1997, pp. 1-36. }\end{array}$ & Susan J. Linz & July 1996 \\
\hline $\begin{array}{l}\text { No. 9: Corporate Debt Crisis and Bankruptcy } \\
\text { Law During the Transition: The Case of China }\end{array}$ & David D. Li and Shan Li & December 1995 \\
\hline $\begin{array}{l}\text { No. } 8 \text { Published in: Journal of Comparative } \\
\text { Economics, "A Theory of Ambiguous } \\
\text { Property Rights in Transition Economies: The } \\
\text { Case of the Chinese Non-State Sector." Vol. } \\
\text { 23, No. 1, August 1996, pp. 1-19. }\end{array}$ & David D. Li & June 1996 \\
\hline $\begin{array}{l}\text { No. 7: The Foreign Economic Contract Law of } \\
\text { China: Cases and Analysis }\end{array}$ & Dong-lai Li & June 1993 \\
\hline $\begin{array}{l}\text { No. 3: Bank Privatization in Hungary and the } \\
\text { Magyar Kulkereskedelmi Bank Transaction }\end{array}$ & Roger Kormendi and Karen Schnatterly & May 1996 \\
\hline $\begin{array}{l}\text { Replacing Nos. 1-2 \& 4-6: Journal of } \\
\text { Comparative Economics Symposium on } \\
\text { "Bank Privatization in Central Europe and } \\
\text { Russia." Vol. 25, No. 1, August } 1997 .\end{array}$ & $\begin{array}{l}\text { No. } 1 \text { "Bank Privatization in Transitional } \\
\text { Economies" by Roger Kormendi and } \\
\text { Edward Snyder. No. } 2 \text { "Transactional } \\
\text { Structures of Bank Privatizations in } \\
\text { Central Europe and Russia" by Anna } \\
\text { Meyendorff and Edward A. Snyder. No. } 4 \\
\text { "Bank Privatization in Poland: The Case of } \\
\text { Bank Slaski” by Jeffery Abarbaness and } \\
\text { John Bonin. No. } 5 \text { "Bank Privatization in } \\
\text { Post-Communist Russia: The Case of } \\
\text { Zhilsotsbank" by Jeffery Abarbanell and } \\
\text { Anna Meyendorff and No. } 6 \text { "'The Czech } \\
\text { Republic's Commercial Bank: Komercni } \\
\text { Banka" by Edward A. Snyder and Roger }\end{array}$ & August 1997 \\
\hline
\end{tabular}

Working Papers are available at: www.wdi.bus.umich.edu 


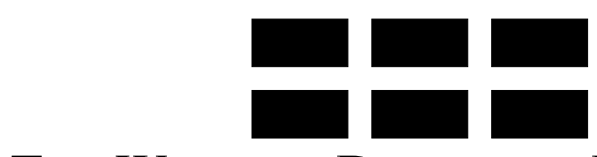

THE WILLIAM DAVIDSON INSTITUTE

AT THE UNIVERSITY OF MICHIGAN BUSINESSSCHOOL

C. Kormendi.

$+$

Working Papers are available at: www.wdi.bus.umich.edu 